\title{
PÓS-GRADUAÇÃO: O CURSO DE DOUTORADO EM CIÊNCIAS CONTÁBEIS DA FEA/USP
}

\section{GRADUATE EDUCATION: THE DOCTORAL COURSE IN ACCOUNTANCY AT FEA/USP}

JACQUELINE VENEROSO ALVES DA CUNHA

Professora Doutora do Programa de Pós-Graduação em Ciências Contábeis da Universidade Regional de Blumenau E-mail:jvac@furb

\section{EDGARD B. CORNACHIONE JR.}

Pesquisador/Instrutor Visitante do Department of Human Resource Education do College of Education da University of Illinois at Urbana-Champaign (USA) e Professor Associado do Departamento de Contabilidade e Atuária da Faculdade de Economia, Administração e Contabilidade da Universidade de São,Paulo E-mail: edgardbc@usp.br

GILBERTO DE ANDRADE MARTINS

Professor Titular do Departamento de Contabilidade e Atuária da Faculdade de Economia, Administração e Contabilidade da Universidade de São Paulo E-mail:martins@usp.br

\section{RESUMO}

O segmento de Cursos de Pós-Graduação Stricto Sensu brasileiros apresentou um crescimento notável nos últimos anos. De 1976, ano em que teve início o processo de avaliação dos Cursos de Pós-Graduação pela Capes, a 2004, os cursos recomendados passaram de um total de 673, (desses, 183 doutorados) para 2.993 (sendo 1.034 doutorados). $\mathrm{Na}$ área de Ciências Contábeis, segundo dados da Capes existem 16 programas. Um deles, o Programa de PósGraduação em Ciências Contábeis da FEA/USP detém o único curso de doutorado na área existente no país. Dado o seu ineditismo e sua importância, o objetivo geral desta pesquisa foi resgatar a história do Programa de PósGraduação do Departamento de Contabilidade e Atuária da FEA/USP. Para atender a esse objetivo a trajetória metodológica envolveu, além da pesquisa bibliográfica, o levantamento histórico de documentação e entrevistas. O programa nasceu da vontade, necessidade e perseverança dos professores do departamento. Concluiu-se que o programa se encontra consolidado e tem no corpo docente seu ponto mais forte. A endogenia apresenta-se como o ponto mais fraco.

Palavras-chave: Doutorado. Ciências Contábeis. Pós-graduação.

\section{ABSTRACT}

Brazilian graduate programs have experienced a remarkable growth in recent years. From 1976, when the CAPES evaluation process of graduate programs began, till 2004, the recommended courses increased from 673 (183 doctoral programs) to 2,993 (1,034 doctoral programs). There are 16 programs in the Accountancy area, according to Capes. One of them, the graduate Accounting program at FEA/USP offers the sole Brazilian PhD program in the field. Due to its importance and novelty, the goal of this research was to retrieve the history of the graduate Accounting program offered by the department of Accountancy and Actuarial Science at FEA/USP. To achieve this goal, the method involved not only a literature review, but also a historic survey of documents and interviews. The program was born from the will, need and perseverance of the faculty members at the department. We conclude that the program has reached a consolidated stage, with its faculty members as its main strength, and its endogenous growth as its main weakness.

Keywords: PhD. Accountancy. Graduate Education. 


\section{INTRODUC̣ÃO}

Ao serem analisados os dados da Coordenação de Aperfeiçoamento de Pessoal de Nível Superior (Capes), instituição responsável pelo acompanhamento e avaliação dos Cursos de Pós-Graduação Stricto Sensu brasileiros, comprova-se o notável crescimento desse segmento no Brasil. De 1976, ano em que teve início o processo de avaliação dos Cursos de Pós-Graduação pela Capes, a 2004, os cursos recomendados passaram de um total de 673, (desses, 183 doutorados) para 2.993 (sendo 1.034 doutorados). O país que, em 1987, contava com 7.914 alunos matriculados nos cursos de doutorado passou, em 2003, a contar com 40.213. O número de titulados (mestrado e doutorado) saiu de $7.039 \mathrm{em} 1990$ para $35.724 \mathrm{em}$ 2003. Nesse mesmo período, o número de doutores subiu de 1.302 para 8.094 (CAPES, 2004). Nos EUA, com uma pós-graduação de proporções gigantescas, são outorgados mais de 38.000 novos títulos ao ano (CHUBIN; ROBINSON, 1992, p. 334).

O segmento público, no Brasil, é responsável pela oferta de $82 \%$ dos cursos de mestrado e $90 \%$ dos de doutorado. O segmento privado, também, cresceu muito na pós-graduação, a exemplo do ocorrido na graduação. Em 1996, era responsável por 87 cursos de mestrado e 44 de doutorado; em 2004, esse número passou para 346 e 96 , respectivamente (CAPES, 2004).

No entanto, segundo Guimarães e Caruso (1996), a capacitação docente não acompanhou o inegável sucesso da pós-graduação, principalmente quando analisada regionalmente; primeiramente, pela adoção do modelo seqüencial no país, com o mestrado constituindo-se em pré-requisito para o doutorado, elevando o tempo médio para titulação; segundo, pela competição do mercado não acadêmico com a academia na disputa pelos egressos e, finalmente, em função da relativa perda de prestígio das profissões acadêmicas com a exaltação do business (mercado corporativo).

É verdade que ainda existem muitas assimetrias estaduais na oferta da pós-graduação. Dos 2.993 cursos existentes em 2004, pode-se verificar que a região Sudeste absorve 1.765 (59\%) cursos de pós-graduação, sendo 1.076 mestrados e 689 doutorados; é seguida pela região Sul com 561 (19\%), sendo 384 mestrados e 177 doutorados; pela região Nordeste com 412 (14\%), sendo 305 mestrados e 107 doutorados; pela região Centro-Oeste com 168 (5\%), sendo 126 mestrados e 42 doutorados; e pela região Norte com 87 (3\%), sendo 68 mestrados e 19 doutorados (CAPES, 2006a).

Até meados da década de 1980, no entanto, acima de $40 \%$ dos títulos dos doutores brasileiros haviam sido obtidos em uma instituição estrangeira. Na segunda metade dos anos 1990, apenas 20\% deles foram obtidos na mesma origem (VELLOSO, 2002, p. 39). A política expansionista, que deu prioridade à formação de doutores, conseguiu atingir seus objetivos e o país aumentou sua taxa de doutores titulados a cada 100 mil habitantes: de 0,82 em 1990 para 3,50 em 2001. Essa taxa de crescimento médio de $14,23 \%$ ao ano foi maior do que a de países como EUA, França, Alemanha, Reino Unido, Japão e Coréia do Sul (MARCHELLI, 2005, p. 9). Muito provavelmente, o motivo é que o projeto educacional desses países já está consolidado e não em implantação como o brasileiro.

Em decorrência do aumento acentuado no número de doutores, a pesquisa passou a ocupar um lugar de destaque nas universidades brasileiras. Em 1990, das 131.641 funções docentes em exercício no ensino superior, apenas 16.939 delas eram ocupadas por titulados com grau de doutor (representando 12,8\%). Em 1998, esse número subiu para 31.073 doutores em 165.122 funções docentes, representando 19,8\% (INEP). Nos primórdios de nossas instituições universitárias (nos idos de 1920), a única missão delegada a elas era a institucionalização do ensino de terceiro grau. A primeira universidade brasileira, a Universidade do Rio de Janeiro (1920), era apenas nominal, sem integração acadêmica, constando que foi criada somente para conceder o título honoris causa ao rei Adolfo, da Bélgica (GRACELLI; CASTRO, 1985, p. 189). Com notável exceção da Universidade de São Paulo (USP) (1934), a pesquisa sequer era tolerada nos primeiros tempos (GUIMARÃES, 2002, p. 45). A USP foi criada pelo Decreto Estadual $n^{\circ}$. 6.283 de 25/01/1934, assinado pelo então interventor $\mathrm{Ar}$ mando de Salles Oliveira, com a pretensão cultural e científica de ser a primeira universidade no país digna desse nome, em que nada mais fosse feito, além da ciência, e com a ambição de ajudar a reconquistar a liderança nacional que o Estado de São Paulo havia perdido com a revolução de 1930 (SCHWARTZMAN, s.d., p. 1).

Entretanto, o avanço brasileiro nas titulações e cursos de Pós-Graduação Stricto Sensu mostra-se totalmente incipiente quando tratado sob a óptica da área de Ciências Contábeis. Apesar da elevação no número de cursos de graduação, de concluintes, abertura de vagas, inscrições e ingressantes, a exemplo de todo o sistema em geral, os Programas de Pós-Graduação Stricto Sensu em Ciências Contábeis não acompanharam esse avanço. Apenas para servir como parâmetro, em 1997, o Curso de Graduação em Ciências Contábeis era o sexto em número de concluintes no país (10.566, representando 3,9\% do total). Em 1998, era o nono em número de inscrições para acesso (91.843 ou $3,2 \%$ do total), o sexto em número de vagas (40.575 ou $5,2 \%$ ) e o quinto em número de alunos matriculados com 122.427 (INEP, 2000).

Segundo dados da Capes ${ }^{1}$, existem 16 Programas de Pós-Graduação cujas áreas de concentração são a Contabilidade, a Controladoria, a Controladoria e Contabilidade e as Ciências Contábeis. Três deles tiveram seus processos reconhecidos em 2007: Universidade Federal de Minas Gerais (UFMG), Universidade Federal da Bahia (UFBA) e

1 Consulta realizada em 04 de julho de 2007 
Universidade Federal do Amazonas (UFAM) (em nível profissional). Dois deles, reconhecidos em 2003, mantêm o Mestrado Profissional: a Fundação Instituto Capixaba de Pesquisas em Contabilidade, Economia e Finanças (Fucape) e a Universidade Federal do Ceará (UFC). Os outros onze contam com o Mestrado Acadêmico: Universidade de Brasília (UNB) com o Programa Multiinstitucional e Inter-Regional UNB/UFPB/UFRN (Universidades Federais da Paraíba e Rio Grande do Norte, reconhecido em 2000), Universidade Federal do Rio de Janeiro (UFRJ) (reconhecido em 1999), Universidade do Estado do Rio de Janeiro (UERJ) (homologado pelo Conselho Nacional de Educação - CNE em 2006), Universidade do Vale do Rio dos Sinos (Unisinos) (reconhecido em 2001), Universidade Regional de Blumenau (Furb) (reconhecido em 2006), Pontifícia Universidade Católica de São Paulo (PUC/SP), Universidade Federal do Paraná (UFPR) (reconhecido em 2006), Universidade Federal de Santa Catarina (UFSC) (reconhecido em 2004), Universidade de São Paulo (USP), Universidade de São Paulo - Ribeirão Preto (USP/RP), Centro Universitário Álvares Penteado (Unifecap) (reconhecido em 2001). Vale ressaltar que, até 1999, eram apenas três os cursos: UERJ, PUC/SP e USP.

No âmbito do Doutorado em Ciências Contábeis a USP mantém a hegemonia. A UNB, até 2007, estava com seu Programa Multiinstitucional e Inter-Regional UNB/UFPB/ UFRN reconhecido e homologado pelo CNE desde 2006, no entanto, não entrou em funcionamento. Apenas para fins de comparação, conforme Hasselback ${ }^{2}$ (2007), nos EUA são 91 os programas de doutorado em Contabilidade, ativos, em escolas acreditadas pela Association to Advance Collegiate Schools of Business (AACSB).

Estabelecido um cenário peculiar do sistema de pósgraduação na área de Ciências Contábeis é objetivo geral deste estudo resgatar a história do Programa de Pós-Graduação do Departamento de Contabilidade e Atuária da FEA/USP.

Sob essa perspectiva, a presente pesquisa justifica-se, dada a importância atribuída à construção de uma plataforma que resgata a história do programa de doutorado em Ciências Contábeis pioneiro e ainda único no país.

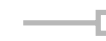

\section{TRAJETÓRIA METODOLÓGICA}

A elaboração deste estudo, com abordagem histórica, envolveu, além de pesquisa bibliográfica, o levantamento histórico de documentação e a realização de entrevistas, para a construção de uma retrospectiva histórica da FEA, do Departamento de Contabilidade e Atuária e do Programa de Pós-Graduação em Ciências Contábeis, particularmente do Curso de Doutorado.

\subsection{Levantamento histórico e entrevistas}

Para proceder ao levantamento da história da FEA/USP, do Departamento de Contabilidade e Atuária e do Programa de Pós-Graduação em Ciências Contábeis, acreditavase que o caminho seria a pesquisa bibliográfica. Afinal, em 2007, encontrava-se em andamento evento comemorativo dos 60 anos da FEA/USP inclusive com um website à disposição com a história da Faculdade e trabalho realizado pela Profa. Diva Benevides Pinho, também em comemoração ao sexagenário. Além disso, há o trabalho publicado pela Profa. Alice Piffer Canabrava, em 1984, considerado marco nas comemorações dos 35 anos da Faculdade, ocorridos há 25 anos. No entanto, foi preciso muito mais. A retrospectiva existente até então era bastante genérica, resgatando parte da memória da FEA/USP e do Departamento de Contabilidade e Atuária, mas muito pouco da história do Programa de Pós-Graduação em Ciências Contábeis. Assim, para proceder a essa pesquisa histórica, foi preciso mais do que apenas a consulta a esse valioso material.

Primeiramente, foi solicitado à Secretaria de Pós-Graduação que disponibilizasse arquivos de defesas, pastas de processos de pedidos de implantação do mestrado, do doutorado e de suas alterações sofridas ao longo dos anos. A consulta a esse material foi realizada e, para complementação, realizaram-se entrevistas com algumas pessoas que haviam vivido o processo e que fizeram parte da trajetória do programa.

$O$ instrumento de coleta de dados escolhido foi a entrevista porque nela existe a oportunidade de observação do entrevistado e de maior flexibilidade na obtenção das informações, visto que entrevistador e entrevistado se encontram face a face. É a técnica mais adequada para revelar informações sobre assuntos considerados complexos, emocionalmente carregados ou, ainda, verificar sentimentos subjacentes a determinada opinião apresentada (SELLTIZ et al., 1967, p. 272). É mais utilizada em pesquisas qualitativas, pois permite exploração ilimitada dos tópicos (GALL; GALL; BORG, 2007, p. 229).

As entrevistas foram realizadas no período de 09/04/2007 a 13/04/2007, conduzidas pela própria pesquisadora e gravadas, com o consentimento dos entrevistados. Foi elaborado um roteiro para sua condução, no entanto, deixando espaço para que o entrevistado se sentisse à vontade nas suas colocações. Foram entrevistados os Professores Sérgio de ludícibus (Professor Emérito da FEA/USP, chefe de departamento quando da proposta de implantação do doutorado e no seu credenciamento) e Eliseu Martins (Professor titular da FEA/USP, ex-coordenador do programa de pós-graduação e um dos responsáveis pela proposta do doutorado), expressões vivas da memória do programa; Masayuki Nakagawa (ex-coordenador do programa de pós-graduação e um dos dez primeiros doutores titulados); Lázaro Plácido Lisboa, Diogo Toledo

2 Disponível no website de James R. Hasselback <http://www.jrhasselback.com/>. Acesso em: 03 fev. 2007. 
do Nascimento e Fábio Frezatti (ex-coordenadores do programa); Ariovaldo dos Santos (coordenador do programa de recepção de professores de universidades públicas para realização do mestrado) e Gilberto de Andrade Martins (atual coordenador do programa).
Após a construção dos textos a partir das entrevistas, enviou-se o material a cada entrevistado, para que pudesse dar seu consentimento final para a publicação.

\section{PLATAFORMA HISTÓRICA}

\subsection{Origem do doutorado}

Segundo Clark (1992, p. 98), o Ph.D. - Doctor of Philosophy americano, no qual o modelo atual brasileiro se inspirou, tem suas raízes nas universidades alemãs. Em 1810, Johann Fichte (Universidade de Berlim) instituiu o Doctor of Philosophy e a "dissertatio doctoralis" passou a ser produzida e examinada publicamente com ênfase numa pesquisa criativa e original. No século XIX, os Doctors of Philosophy multiplicaram-se. Mais recentemente, ocorreu o caminho inverso, com o modelo americano de pós-graduação inspirando iniciativas na organização de escolas francesa, alemã e holandesa (VELHO, 1998, p. 92).

Park (2005, p. 191-192) confirma que foi na Alemanha que o doutorado adquiriu um status especial como grau de pesquisa, devendo seu desenvolvimento, em grande parte, à iniciativa e visão de Humboldt. Foi ele o fundador da primeira universidade de pesquisa moderna, a University of Berlin, em 1810 (WYATT, 1998).

O prêmio pelo doutorado alemão exigia presença bem sucedida em aulas, submissão de uma tese aceitável e a passagem por um exame oral abrangente. A ênfase era sobre uma pesquisa criativa e original (GOODCHILD; MILLER, 1997).

Entretanto, Engel (1966, p. 781) relata que a origem das teses é anterior ao seu uso na educação científica por diversos séculos. Elas apareceram no Século XIII, quando Saint Bonaventure conferiu a prática de descrever e defender uma tese ou doutrina para a entrada de futuros colegas na Ordem Franciscana. As universidades medievais seguiram esse guia e adotaram a prática de geração e defesa de teses, que mais tarde se tornou uma exigência para a conquista de um grau avançado (BOWEN, 2004, p. 4).

Logo no início, em torno de 1815, a credibilidade e vitalidade acadêmicas das universidades alemãs atraíram estudantes brilhantes e ambiciosos, graduados na Inglaterra e na América que não tinham oportunidades adequadas em seus países de origem (SIMPSON, 1983; EIDMANN, 2002). Quando retornavam eram empregados por universidades e instituições de ensino superior (colleges), ajudando, assim, a elevar o perfil da pesquisa acadêmica em seus países de origem, principalmente nas universidades norte-americanas (SCHATTE, 1977).

Clark (1992, p. 99-102) esclarece que, na Idade Média, obter o degree habitava a mesma esfera de um título de nobreza. Os estatutos estabeleciam que os candidatos estavam sujeitos: a linhagem legítima, condição de cristãos, homem, idade certa e, como o conhecimento era considerado perigoso, também deveriam se submeter a três testes de coragem. O título, portanto, era o grau com a mais alta dignidade. De
1450 a 1550, seu prestígio declinou por duas razões: (1) em 1450, o primeiro alemão acadêmico retornou da Itália como humanista e ridicularizou o título chamando-o de farsa. Rejeitou-o e adotou o de "Poeta" em seu lugar; (2) doutores em Teologia, Jurisprudência e Medicina não necessitavam de títulos para existir e argumentavam que os privilégios dos verdadeiros "doutores" não deveriam se estender a outros que não estivessem dentro dos três campos estabelecidos. $E$ os privilégios não eram poucos. Incluíam desde o direito de parar a construção de um prédio, sentar na presença de magistrados, vestir a mesma roupa dos nobres e ter preferência ao lado deles até o benefício em caso da dúvida em suspeita de crimes, não podendo ser torturados.

$\mathrm{Na}$ universidade medieval chamavam-se mestres todos os licenciados que faziam parte da corporação dos professores de todas as faculdades, com exceção da Faculdade de Direito, na qual os professores se intitulavam doutores. Após o Renascimento o grau de Mestre tende a desaparecer nas instituições européias (PARECER CESu/CFE 977/65).

Na Inglaterra, o Doctor of Science entrou na University of London entre 1857 e 1860, na Cambridge University apenas em 1882 e a Oxford University só outorgou seu primeiro Doctor of Philosophy em 1917. A propagação do Doctor of Philosophy teve, como maior resultado, o desenvolvimento da pesquisa universitária.

A partir de 1860, os EUA começaram a importar da Alemanha as noções de pesquisa universitária e graus de doutorado (PARK, 2005). A Universidade de Yale foi a primeira a adotar o grau de Ph.D., em 1861 (PARK, 2005, p. 192; EIDMANN, 2002, p. 14; CLARK, 1992, p. 98). Foi seguida pelas Universidades de Harvard, Michigan e Pennsylvania (PARK, 2005, p. 192). O Ph.D. de Yale exigia que os estudantes terminassem cursos especializados, se alistassem por três anos, demonstrassem proficiência em pelo menos uma língua estrangeira, se submetessem a um exame abrangente, apresentassem uma tese e fossem avaliados em um exame oral (BUCHANAN; HERUBEL, 1995). A expansão foi rápida na América do Norte, entre 1870 e 1900 e, no final do século XIX, o Ph.D. havia se tornado o sine qua non dos professores universitários americanos (SIMPSON, 1983).

Também foi o desenvolvimento alemão que levou para o padrão das teses de Ph.D. (ENGEL, 1966, p. 783) dirigidas para produzir contribuições originais, permanecendo a marca do estudo doutoral. É importante reconhecer que a maioria dos Ph.Ds. outorgados no século XIX, na América, eram honorários. Os graus eram conferidos por diversas razões, como, por exemplo, anos de estudos acumulados, ao invés de ser por um estudo rigoroso e uma contribuição 
original para a disciplina. Apenas após a virada do século XIX é que a prática de outorgar os graus de doutorado como efetivamente conquistados tornou-se mais padronizada (STRICKER, 1973).

Uma tese representa a "pedra superior" do doutoramento. Seu término e a conseqüente defesa e aceitação estão intimamente associados com a conferência do grau de doutor. Sua intenção é representar as habilidades adquiridas e o conhecimento na aplicação de um projeto de pesquisa apropriado, a perícia do estudante em certa área de estudo e a sua contribuição original para o campo do conhecimento. Rigor apropriado deve ser demonstrado no desenvolvimento da investigação científica, revisão da literatura, aplicação de metodologia e análise empírica apropriadas, e defesa do seu projeto, análise dos resultados e implicações sob exame detalhado de um comitê de profissionais (BOWEN, 2004, p. 6).

\subsection{A Pós-Graduação no Brasil}

No Brasil, a gestação da pós-graduação durou pelo menos 30 anos. A primeira reforma educacional de caráter nacional foi realizada no início da era Vargas (19301945), autorizando e regulamentando as universidades e estabelecendo sua finalidade social. Foi instaurada pelo primeiro Ministro da Educação e Saúde, Francisco Campos (o Ministério da Educação e Saúde fora instituído em 1930), por meio do Decreto 19.851/31. Essa reforma ficou conhecida como Reforma Francisco Campos e previa que, nos institutos de ensino superior, seriam realizados os cursos normais, equiparados, de aperfeiçoamento, de especialização, livres, de extensão e de doutorado, que se destinavam a prolongar a atividade técnica e científica dos institutos universitários, em benefício da coletividade. As normas para o doutoramento baseado no modelo europeu, principalmente o francês, ficam estabelecidas (GRACELLI; CASTRO, 1985, p. 189; SPAGNOLO; GÜNTHER, 1986, p. 1644). Mesmo a reforma representando um avanço, uma reivindicação do movimento da década de 1920 não foi atendida: a não exclusividade pública ao ensino superior além de permitir o funcionamento de instituições isoladas (MARTINS, 2002, p. 5). Os primeiros cursos com o nome de Pós-Graduação só surgem no país a partir de 1946 na Universidade do Brasil (MARTINS; SERRA, 1998, p. 20). Mesmo assim, não havia o mestrado e o título de doutor era ostentado por um número muito reduzido de pessoas (BEIGUELMAN, 1998, p. 33).

Entretanto, a pós-graduação só foi regulamentada mais de 30 anos depois, pelo Parecer $n^{\circ}$. 977/65 do Conselho de Educação Superior (CESu), aprovado em 03/12/1965. Esse parecer definiu e fixou as características dos cursos de mestrado e doutorado, traçando o perfil da pós-graduação brasileira e estruturando-a no modelo do sistema norteamericano, além de distinguir a Pós-Graduação Lato Sensu da Stricto Sensu. O Quadro 10, mostra as características do sistema de Pós-Graduação norte-americano, inspiração para a construção do modelo brasileiro.

\footnotetext{
1. A pós-graduação constitui-se num sistema de cursos que procedem ao bacharelado, conferido pelo college;
}

2. Confere os graus de Mestre (M. A. - Master of Arts ou M. S. - Master of Science) e de Doutor (Ph.D, Philosophiae e Doctor);

3. Mestrado e Doutorado representam dois níveis que se hierarquizam, entretanto, são autônomos;

4. O doutorado em pesquisas, o Ph.D, é o mais importante dos graus acadêmicos conferidos pela universidade;

5. Os doutorados profissionais têm como exemplo Doutorado em Engenharia, em Administração;

6. O Mestrado tanto pode ser de pesquisa quanto profissional;

7. O Ph.D. não exige, necessariamente, o Mestrado;

8. O Mestrado é útil como sinal de competência profissional, para o magistério secundário e garantia de melhor remuneração;

9. O Ph.D. é o título necessário para o acesso na carreira de professor universitário;

10. Teoricamente, requer-se um ano para o Mestrado e dois anos para o Ph.D.;

11. Exige-se frequência regular aos cursos para a obtenção dos créditos;

12. Os critérios de admissão são tanto mais severos quanto mais alto for o padrão da universidade;

13. Para o Ph.D há exigência da tese, para o M. A. pode ser dissertação, memória ou ensaio, ou apenas os exames prestados;

14. O método de instrução, por excelência, é o seminário;

15. A pós-graduação não se limita ao preparo da tese ou dissertação;

16. O aluno está obrigado a uma série de cursos com o intuito de proporcionar-lhe sólida formação científica.

Fonte: Parecer 977/65 CESU/CFE

Quadro 1 - Características do sistema de pós-graduação norte-americano 
Nesse momento, encontravam-se em funcionamento, no país, 27 cursos classificados no nível de mestrado e 11 de doutorado (FAPESP, 2001). O referido parecer destaca que a implantação de estudos de pós-graduação "[...] é condição básica para transformar a universidade brasileira em centro criador de ciências, artes e tecnologias".

A Pós-Graduação Lato Sensu foi definida como representando todo e qualquer curso que se segue à graduação. Normalmente cursos destinados ao treinamento, com objetivo técnico profissional específico sem abranger o campo total do saber em que se situa a especialidade. Como meta, o domínio técnico-científico de uma área certa e limitada do saber ou da profissão, para a formação do profissional especializado. Como características fundamentais: (1) o sentido eminentemente prático-profissional e (2) conceder certificado (Parecer 977/65).

A Pós-Graduação Stricto Sensu definiu o sistema de cursos que se sobrepõe à graduação com objetivos mais amplos e aprofundados de formação científica ou cultural. Apresenta como características fundamentais: (1) a natureza acadêmica e de pesquisa e mesmo atuando em setores profissionais tem objetivo essencialmente científico; (2) conferir grau acadêmico e (3) possuir uma sistemática formando estrato essencial e superior na hierarquia de cursos que constituem o complexo universitário (PARECER CESu/CFE 977/65).

A definição e as características do mestrado e doutorado, conforme texto do Parecer 977/65, compreendiam, dentre outras coisas, a divisão do programa de estudos em duas fases: a primeira, compreendendo a freqüência às aulas e culminando com um exame geral para a verificação do aproveitamento; a segunda, dedicada à investigação para a preparação da dissertação ou tese; a eleição do crédito ou das unidades equivalentes como unidade de medida dos estudos exigidos; o total de 360 a 450 horas de trabalhos escolares, aulas, seminários ou atividades de laboratórios, por ano letivo.

Em suas conclusões, o Parecer 977/65 formulou as características fundamentais dos cursos de pós-graduação correspondentes aos dois níveis: mestrado e doutorado, com duração mínima de 1 (um) e 2 (dois) anos, respectivamente, hierarquizados, mas não se constituindo o primeiro em condição indispensável à inscrição no segundo. A exigência para a matrícula em qualquer dos dois níveis é o diploma do curso de graduação, cabendo às instituições estabelecer os requisitos para a seleção. Preparação de dissertação (mestrado) ou tese (doutorado) com a assistência de orientador, cumprimento de disciplinas, exames parciais e gerais e provas de proficiência em língua estrangeira. A orientação é para que a pós-graduação se faça em regime de tempo integral.

Pode-se observar, pelas definições, pelo que pôde ser visto no Quadro 1 e pela análise do Parecer 977/65, que o modelo brasileiro reteve do sistema norte-americano alguns aspectos. Dentre eles: os dois níveis (mestrado e doutorado), distinção entre mestrado profissional e de pesquisa; a sistemática de créditos; duração variável; exames de qualificação, domínio de língua estrangeira; acompanhamento dos estudos e pesquisas por um orientador e exigência de dissertação para o mestrado e tese para o doutorado.

Durante as três décadas de intervalo entre a primeira reforma educacional de caráter nacional (1931) e a regulamentação da pós-graduação pelo Parecer 977/65, nos moldes do modelo norte-americano, o ensino para graduados assumiu a forma de cursos de aperfeiçoamento e especialização, conforme definido no art. 35 do Decreto 19.851/31, com os primeiros destinados a ampliar conhecimentos, enquanto os segundos estavam destinados a aprofundar os conhecimentos necessários às finalidades profissionais ou científicas. Tornam-se efetivas as normas de cursos de doutoramento definidas pelo Decreto 19.851/31 - ainda seguindo a tradição européia. Registre-se, nesse intervalo, a criação da Faculdade de Filosofia, Ciências e Letras da Universidade de São Paulo, em 1934, e a vinda de vários cientistas europeus implementando o doutorado segundo o modelo das universidades européias, iniciando-se no Brasil a prática da pesquisa no seio da universidade (GRACELLI; CASTRO, 1985, p. 189; SPAGNOLO; GÜNTHER, 1986, p. 1644). A marca das atividades de pesquisa comprova-se pelos registros dos candidatos ao doutorado, que, de um modo geral, haviam passado pelos programas de iniciação científica durante a graduação. A relação dos doutorandos com o professor-orientador obedecia a um caráter quase tutelar, sendo que o título de doutor não conferia vantagens financeiras ou profissionais ao portador, apenas demonstrava prestígio e competência em pesquisa. Em casos especiais e com a comprovação de trabalhos publicados, era possível defender tese sem a presença de um orientador (BEIGUELMAN, 1998, p. 34).

Podem-se distinguir alguns fatores que concorreram para a implantação do sistema de pós-graduação e o desenvolvimento científico e da pesquisa brasileiros nesses mais de 30 anos que transcorreram entre o Decreto 19.851/31 e o Parecer 977/65: (1) a criação, em 1948, da Sociedade Brasileira para o Progresso da Ciência (SBPC), catorze anos depois da fundação da Universidade de São Paulo, como fruto de um movimento de afirmação do pensamento científico, bastante motivado pela chegada ao país de grandes cientistas europeus. O fator decisivo para a constituição da entidade foi a iniciativa intervencionista do então Governador de São Paulo, Adhemar de Barros, de transformar um instituto de pesquisas - o Butantã - em uma instituição apenas produtora de soros antiofídicos. Para fazer frente a essa interferência e a outros problemas semelhantes, os cientistas resolveram criar uma associação para defender os seus interesses e lutar pelo progresso da ciência (SPAGNOLO; GÜNTHER, 1986, p. 1644; SBPC, 2006); (2) a criação da Coordenação de Aperfeiçoamento de Pessoal de Nível Superior (Capes), com o objetivo de assegurar a existência de pessoal especializado em quantidade e qualidade suficientes para atender às necessidades dos empreendimentos públicos e privados que visam ao desenvolvimento do país e, também, do Conselho Nacional de Pesquisas (CNPq), destinado ao fomento da pesquisa científica e tecnológica e à formação de recursos humanos para a pesquisa no país, ambos em 1951. Esses 
órgãos de fomento mantinham missões paralelas: a Capes voltada a questões de ensino e o CNPq com preocupações inerentes à pesquisa (GRACELLI; CASTRO, 1985, p. 190; SPAGNOLO; GÜNTHER, 1986, p. 1644).

A institucionalização da pós-graduação veio com a Lei 5.540/68 (Lei da Reforma Universitária), que definiu como seus objetivos: a) formar professores para o ensino superior; b) preparar pessoal de alta qualificação para as empresas públicas e particulares; c) estimular estudos e pesquisas científicas por meio da formação de pesquisadores, que servissem ao desenvolvimento do país.

A partir da institucionalização da referida lei, teve início um período de acelerado crescimento no sistema de pósgraduação do país, coincidente também com a aprovação do Parecer $n^{\circ}$. 77/69 do Conselho Federal de Educação, estabelecendo as normas para credenciamento dos cursos de Pós-Graduação Stricto Sensu, que deveriam obter a maioria dos votos dos conselheiros e serem homologados pelo Ministro da Educação. Exigia-se um alto padrão dos cursos, com corpo docente altamente qualificado (com título de doutor), equipamentos, laboratórios, pesquisas e publicações em livros ou revistas científicas além de serem realizadas visitas in loco (PARECER CFE $n^{\circ}$. 77/69).

O grande momento dessa expansão ocorreu entre 1969 e a década de 1970, quando o próprio país atravessou uma grande fase de expansão econômica, sobretudo no setor particular, que, até o momento, não havia direcionado seus recursos para esse nível de ensino. Em 1969, havia 135 cursos de pós-graduação que passaram para 462 em 1972, 764 em 1976 e 974 em 1979 (GRACELLI; CASTRO, 1985, p. 191; SPAGNOLO; GÜNTHER, 1986, p. 1644; CURY, 2005, p. 16).

Gracelli e Castro (1985, p. 199) concluem que, apesar de a pós-graduação ter começado muito tarde, um século depois da norte-americana, seu ritmo de crescimento foi o mais alto jamais experimentado por qualquer nível de ensino do Brasil até então. Com o retorno dos primeiros mestres e doutores, que, inicialmente, passaram por um período de formação principalmente no exterior, começaram a ser criados os programas. Detectaram três focos para o ímpeto e velocidade na abertura dos cursos: (1) a institucionalização da pós-graduação com a Lei 5.540/68 e posteriores medidas institucionais para o aprimoramento do quadro docente; (2) a expansão do ensino superior e (3) o incentivo financeiro fornecido pelas agências de fomento.

Atualmente, os docentes das universidades públicas continuam impostos a uma titulação pós-graduada stricto sensu para progressão na carreira, o mesmo ocorrendo em algumas instituições de ensino superior particulares (por exemplo, Faculdades Novos Horizontes, Centro Universitário Newton Paiva, Faculdades Ibmec) e órgãos públicos ou autarquias governamentais (Banco Central, Tribunal de Contas do Estado de Minas Gerais, dentre outros). Também, o constrangimento legal das Diretrizes e Bases da Educação Nacional (LDB), Lei n. 9.394/96, que, em seu artigo 52, exige que uma instituição para pleitear as prerrogativas de universidade tenha produção intelectual institucionalizada, um terço do corpo docente, pelo menos, com mestrado e doutorado e um terço com tempo integral.

A configuração atual da pós-graduação brasileira está dividida em ciclos, organizada sob uma moldura legal centralizada, sujeita à avaliação de pares sob o amparo de um órgão específico do Estado e a um financiamento sistemático (FAPESP, 2001). Pode-se, no entanto, creditar ao Parecer 977/65 o título de texto fundador da pós-graduação sistemática no Brasil, sendo que, após sua emissão, parece não haver outro que articule doutrina e normatização ao mesmo tempo sobre o assunto e tenha provocado tanto impacto nesse nível de educação (CURY, 2005, p. 30).

A Capes foi reconhecida como órgão responsável pela elaboração do Plano Nacional de Pós-Graduação Stricto Sensu, em 1981, por meio do Decreto no 86.791. Foi também reconhecida como Agência Executiva do Ministério da Educação e Cultura pelo sistema nacional de Ciência e Tecnologia, cabendo-Ihe elaborar, avaliar, acompanhar e coordenar as atividades relativas à pós-graduação, o que só fortalece seu papel (CAPES, 2006b).

\subsubsection{O sistema de avaliação dos programas Stricto Sensu ${ }^{3}$}

A Capes é quem realiza a avaliação dos programas de pós-graduação, desde sua implantação, ocorrida em 1976. A avaliação da pós-graduação permite-lhe cumprir um papel de fundamental importância para o desenvolvimento da educação e da pesquisa científica e tecnológica no Brasil. A avaliação contribui para: (1) impulsionar a evolução dos programas de pós-graduação, estabelecendo-lhes metas e desafios para o avanço da ciência e tecnologia e aumento da competência nacional nesse campo; (2) aprimorar os programas de pósgraduação, fornecendo-lhes um parecer criterioso da comissão de consultores sobre os pontos fracos e fortes de seu projeto e de seu desempenho e uma referência sobre o estágio de desenvolvimento em que se encontram; (3) estabelecer o padrão de qualidade exigido dos cursos de mestrado e de doutorado, identificando os que atendem a tal padrão; (4) fundamentar os pareceres do Conselho Nacional de Educação sobre autorização, reconhecimento e renovação de reconhecimento dos cursos de mestrado e doutorado brasileiros, exigidos para que possam expedir diplomas com validade nacional reconhecida pelo Ministério da Educação (MEC); (5) o aumento da eficiência dos programas para a formação de recursos humanos de alto nível; (6) dotar o país de um eficiente banco de dados sobre a situação e evolução da pós-graduação e (7) oferecer subsídios para a definição da política de desenvolvimento da pós-graduação e para a fundamentação de decisões sobre as ações de fomento dos órgãos governamentais na pesquisa $e$ pós-graduação. Uma oitava contribuição da avaliação mantida pela Capes, na avaliação de Anuatti Neto (1997, p. 188), seria a introdução de um grau de competição entre os centros de pós-graduação, ao condicionar a obtenção de recursos ao desempenho na avaliação.

3 Todas as informações constantes desse item foram coletadas no site da Capes em: <http://www.capes.gov.br/capes/portal/> item avaliação. Acesso em: 30 ago. 2006c. 
A avaliação da pós-graduação abrange tanto programas de pós-graduação já integrantes do Sistema Nacional de Pós-Graduação (SNPG), por meio de uma avaliação trienal que define quais programas e cursos terão seu "reconhecimento" renovado pelo MEC, vigorando a partir do triênio seguinte; quanto aos novos cursos de doutorado e mestrado, utilizando os mesmos critérios e parâmetros usados na avaliação trienal, sendo que os cursos aprovados passam a integrar o SNPG. Os critérios de avaliação são explicitados por áreas de conhecimento e os quesitos avaliados são a proposta do programa, o corpo docente, as atividades de pesquisa e formação, o corpo discente, as teses e dissertações e a produção intelectual.

Em 1998, foram promovidas significativas alterações no sistema de avaliação. Dentre elas: (1) a adoção do padrão internacional como referência de desempenho para cada área; (2) a adoção de notas de 1 a 7 em substituição à escala anterior de cinco conceitos, de modo a permitir uma maior diferenciação entre os programas; (3) o estabelecimento da nota 3 como padrão mínimo de desempenho para validação nacional dos diplomas emitidos pelos programas de pós-graduação, sendo a atribuição de notas imposta a todos os cursos e (4) a avaliação é feita por programa e não mais por curso.

O significado das notas atribuídas é o seguinte:

I. notas 6 e 7 : apenas para programas com oferta de doutorado com nível de excelência, desempenho equivalente ao dos mais importantes centros internacionais de ensino e pesquisa, alto nível de inserção internacional, grande capacidade de nucleação de novos grupos de pesquisa e ensino e cujo corpo docente desempenhe papel de liderança e representatividade na respectiva comunidade;

II. nota 5: alto nível de desempenho, sendo o maior conceito atribuído aos cursos que ofereçam apenas mestrado;

III. nota 4: bom desempenho;

IV. nota 3: desempenho regular, padrão mínimo de qualidade exigido;

V. notas I e 2: desempenho fraco, abaixo do padrão mínimo de qualidade exigido.

\subsubsection{Estatísticas e tendências da Pós-Graduação Stricto Sensu}

Como se pode observar pelas Tabelas 1, 2 e 3, os resultados são indicadores diretos da evolução do sistema de pós-graduação ao longo do tempo, que, desde sua origem, está associada ao propósito de formação de pesquisadores e professores para a expansão do ensino superior.

$\mathrm{Na}$ Tabela $1 \mathbf{0}$, constata-se o crescimento de quase $300 \%$ nos cursos de mestrado de 1976 a 2004 e de mais de $465 \%$ nos cursos de doutorado. Observe-se que a concentração maior de cursos de doutorado é na área pública. Mesmo assim, o seu crescimento na área privada foi de mais de 100\% num período de 8 anos (1996-2004).

O número de alunos titulados, no período de 1987 a 2003 , apresenta um crescimento superior a $650 \%$ no mestrado e a $830 \%$ no doutorado. Os números para alunos matriculados e alunos novos também apresentaram aumento expressivo: mais de $145 \%$ no mestrado e quase $410 \%$ no doutorado, para o primeiro e cerca de $275 \%$ para o mestrado e 535\% para o doutorado no segundo (Tabela 20 ).

Tabela 1 \Evolução do sistema de pós-graduação 1976 - 2004 - cursos

\begin{tabular}{l|c|c|c|c} 
Número de cursos & $\mathbf{1 9 7 6}$ & $\mathbf{1 9 9 0}$ & $\mathbf{1 9 9 6}$ & $\mathbf{2 0 0 4}$ \\
Mestrado & 490 & 975 & 1.083 & 1.959 \\
\hline Doutorado & 183 & 510 & 541 & 1.034 \\
\hline Doutorados & & & & \\
Federal & & & 230 & 568 \\
\hline Estadual & & & 267 & 370 \\
\hline Particular & & & 44 & 96
\end{tabular}

Fonte: Capes, 2004

Tabela 2 | Evolução do sistema de pós-graduação 1987 - 2003 - alunos

\begin{tabular}{l|r|r|r|r} 
Alunos titulados & $\mathbf{1 9 8 7}$ & $\mathbf{1 9 9 0}$ & $\mathbf{1 9 9 6}$ & $\mathbf{2 0 0 3}$ \\
\hline Mestrado & 3.647 & 5.737 & 10.499 & 27.630 \\
\hline Doutorado & 868 & 1.302 & 2.985 & 8.094 \\
\hline Alunos matriculados & & & & \\
Mestrado & 29.281 & 37.789 & 45.622 & 72.001 \\
\hline Doutorado & 7.914 & 11.210 & 22.198 & 40.213 \\
\hline Alunos novos & & & & \\
\hline Mestrado & 9.440 & 13.014 & 16.457 & 35.305 \\
\hline Doutorado & 1.786 & 2.922 & 5.159 & 11.343 \\
\hline
\end{tabular}

Fonte: Capes, 2004 
A tendência é a de que o crescimento continue. As projeções fazem parte do Plano Nacional de Pós-Graduação 2005-2010 - PNPG, que utilizou um modelo apoiado na variável "número de alunos titulados no doutorado". Essa variável depende do número de alunos novos (ingressados 3,4 e 5 anos antes), do total de alunos matriculados no ano anterior e da evolução das séries históricas. As projeções foram realizadas baseadas em três possíveis cenários: (l) considerando-se que o número de alunos novos continuará crescendo, de forma exponencial, na mesma taxa observada de 1987-2003; (II) considerando-se a média geométrica das estimativas encontradas nos cenários I e III; (III) considerando-se que o número de alunos novos continuará crescendo, de forma linear, baseado no passado recente, 1996-2003. A Tabela 30 permite uma visualização dessas perspectivas.

\subsection{A Pós-Graduação em Ciências Contábeis na FEAVUSP}

O tópico que se desenvolve, a seguir, foi baseado nas seguintes obras: (a) trabalho da Profa. Alice Piffer Canabrava (1984), considerado marco na comemoração dos trinta e cinco anos de existência da Faculdade de Economia, Administração e Contabilidade e no cinqüentenário da Universidade de São Paulo; (b) trabalho da Profa. Diva Benevides Pinho (2006) - A FEA-USP no tempo: contribuição à memória de seus 60 anos; (c) folheto informativo sobre o Programa de Pós-Graduação em Controladoria e Contabilidade (2002); (d) nos websites da FEA/USP e edição comemorativa dos 60 anos da FEA (acesso em 17/04/2007); (e) na legislação pertinente; (f) em entrevistas realizadas, no período de 09/04/2007 a 13/04/2007, com os Professores Sérgio de ludícibus (Professor Emérito da FEA/USP, chefe de departamento quando da proposta de implantação do doutorado e no seu credenciamento); Eliseu Martins (Professor titular da FEA/USP, ex-coordenador do programa de pós-graduação e um dos responsáveis pela proposta do doutorado); Masayuki Nakagawa (ex-coordenador do programa de pós-graduação e um dos dez primeiros doutores titulados); Lázaro Plácido Lisboa, Diogo Toledo do Nascimento e Fábio Frezatti (ex-coordenadores do programa); Ariovaldo dos Santos (coordenador do programa de re- cepção de professores de universidades públicas para realização do mestrado) e Gilberto de Andrade Martins (atual coordenador do programa).

A Faculdade de Economia, Administração e Contabilidade da Universidade de São Paulo foi criada em 1946, com a denominação de Faculdade de Ciências Econômicas e Administrativas (FCEA), no ano seguinte ao que foi criado o curso de Ciências Contábeis e Atuariais em nível superior, pelo Decreto-Lei $n^{\circ} .7988$ de 22/09/1945. Estabelecida pelo Decreto-Lei estadual $n^{\circ} .15 .601$ de 26 de janeiro de 1946 , instalou-se, como instituição da Universidade de São Paulo, nesse mesmo ano, na Rua Dr. Vila Nova. Inicialmente, manteve os cursos de Ciências Econômicas e de Ciências Contábeis e Atuariais, com ingresso mediante exame vestibular e com várias disciplinas em comum. O curso de Administração foi implementado apenas em 1964.

Desde o início da FEA, as cadeiras eram agrupadas em Departamentos, inicialmente com um departamento com função administrativa (Departamento de Publicações) e sete departamentos com função docente - Economia, Administração, Contabilidade e Atuária, Matemática, Estatística, Direito e Ciências Culturais. No entanto, na prática, a estrutura era a de cátedras, conforme consolidado pelos decretos estaduais de criação da USP e aprovação de seus primeiros Estatutos, que eram preenchidas por concurso de títulos e provas. A estrutura departamental existia apenas do ponto de vista legal e regimental durante o período de 1946-1969. Os Assistentes e Auxiliares de Ensino ocupavam funções de confiança dos catedráticos. Para o início do ano escolar de 1946, os catedráticos foram nomeados sem se submeterem a concursos e vários professores foram contratados por três anos, após concurso de títulos. Dentre eles, para o Departamento de Contabilidade e Ciências Atuariais, o Prof. Attílio Amatuzzi, da Fundação Escola de Comércio Álvares Penteado (hoje Fecap) para a Cadeira de Contabilidade Geral e Pública e, no segundo semestre, para a Cadeira de Estrutura de Análise de Balanços, foi contratado o Prof. Francisco D’Áuria. O acesso às cátedras era extremamente restrito e ela só mudava de titular em casos especiais. Para a criação de novas cátedras era necessário passar pelo crivo das já existentes. "A cátedra se constituía na base de poder sobre a política, o ensino, a pesquisa

Tabela 3 - Cenários de crescimento da pós-graduação

\begin{tabular}{l|r|r|r|c}
\multirow{2}{*}{ Doutorado } & \multirow{2}{*}{$\mathbf{2 0 0 3}$} & \multicolumn{3}{|c}{$\mathbf{2 0 1 0}$} \\
\cline { 4 - 5 } & & Cenário I & Cenário II & Cenário III \\
\hline Alunos titulados & 8.094 & 16.918 & 15.280 & 13.818 \\
\hline Alunos novos & 11.343 & 25.739 & 20.679 & 16.754 \\
\hline Alunos matriculados (final do ano) & 40.213 & 70.336 & 63.218 & 56.801 \\
\hline Mestrado & & & & \\
\hline Alunos titulados & 27.630 & 56.956 & 50.910 & 45.667 \\
\hline Alunos novos & 35.305 & 65.496 & 62.156 & 59.065 \\
\hline Alunos matriculados (final do ano) & 72.001 & 106.837 & 104.465 & 102.191 \\
\hline Docentes Doutores atuando na pós-graduação & 32.354 & 52.974 & 49.020 & 45.432
\end{tabular}

Fonte: Capes, 2004 
universitária. Através de uma hierarquia muito bem definida, ao professor catedrático estava subordinado todo o trabalho acadêmico" (ALVES, 1984, p. 114).

O dispêndio financeiro com a manutenção da Faculdade era enorme, comparativamente ao número de alunos que se formavam. A primeira turma a se formar no curso de Ciências Contábeis e Atuariais (no qual o fenômeno era mais sentido) tinha 5 alunos (1949). Entre 1949 e 1960, o número de formandos girou entre 2 e 7 ao ano. A turma titulada em 1961 foi a primeira a superar esse número, contava com 10 formandos, dentre eles os professores Sérgio de ludícibus, Eric Dietrich Lemmermann e Edmundo Éboli Bonini, que, posteriormente, integrariam o corpo docente do Departamento de Contabilidade e Atuária. Nem mesmo a instituição do curso noturno, em 1950, melhorou a situação. Imputam-se como causa as atribuições profissionais e competência legal praticamente idênticas às do bacharel em Ciências Contábeis e Atuariais e do técnico em Contabilidade, curso ministrado pelas Escolas de Comércio. Essa situação perdurou enquanto os alunos fizeram opção pelo curso que pretendiam seguir após a conclusão do primeiro ano. Os que optavam pelo curso de Ciências Contábeis e Atuariais eram sempre em número reduzido. $A$ situação atenuou-se mais recentemente, quando a opção passou a ser exigida no ato da inscrição ao processo vestibular $e$, mais ainda, quando se procedeu à separação das carreiras de Economia, Administração e Ciências Contábeis, após a Reforma Universitária de 1969.

Em 12/05/1958, o Decreto $n^{\circ}$. 32.207, assinado pelo então governador do Estado de São Paulo Jânio Quadros, dispôs sobre o doutoramento na Faculdade de Ciências Econômicas e Administrativas, estabelecendo que a FCEA da USP conferiria o título de doutor aos que fossem aprovados na defesa de uma tese de doutoramento perante uma banca de cinco professores indicados pela Congregação e, previamente, em duas disciplinas subsidiárias. Os diplomas conferidos seriam: doutor em Ciências Econômicas, doutor em Ciências Contábeis e doutor em Ciências Atuariais, devendo ser mencionada no diploma, em subtítulo, a disciplina a que se referia a tese. Os candidatos, quando de sua inscrição, indicariam o assunto de sua tese e poderiam escolher o orientador, que seria designado pela Congregação caso o candidato não o fizesse.

Em 1964, a Faculdade passa por uma reformulação e o Curso de Ciências Contábeis e Atuariais é separado em cursos distintos que outorgam títulos profissionais também distintos: o Curso de Ciências Contábeis formando Contadores e o de Ciências Atuariais formando Atuários. Nos três primeiros anos, as disciplinas eram comuns, diferenciando-se totalmente no quarto ano. O curso de Atuária, no entanto, formou apenas 4 atuários até 1975, quando foi desativado, vindo a ser novamente implementado no ano de 2006.

Em dezembro de 1969, com a reforma estatutária da USP, na esteira da Reforma Universitária promovida pela Lei 5.540/68, as cadeiras dos catedráticos são eliminadas e o Departamento torna-se a menor fração da universidade, no lugar delas. Naquela época, o Departamento de Contabilidade e Atuária tinha apenas o Prof. Antônio Peres Rodrigues Filho, concursado em 1968, como Professor Catedrático da Cadeira VIII - Organização e Contabilidade Bancária; Organização e Contabilidade de Seguros, em substituição ao Prof. Francisco D’Áuria, que se aposentara. A figura máxima da carreira universitária passa a ser o professor titular. Conforme Portaria GR n ${ }^{0} .1 .023$ de 19/01/1970, passa a funcionar o modelo com os três departamentos: Economia, Administração e Contabilidade e Atuária. Neles ficaram distribuídas as disciplinas decorrentes das antigas Cátedras e cada um dos departamentos ficou responsável por um curso de graduação. Muitos dos vínculos entre os três departamentos foram eliminados, apesar da manutenção das relações de cooperação, desaparecendo o curso básico e o vestibular único. Na Reforma, são criadas condições que permitem a ascensão do docente na carreira tão somente pelo seu mérito, de uma forma menos pessoal e mais objetiva. Para tanto, deve ingressar em cursos de mestrado e doutorado. O grau de Professor Adjunto é anterior ao de Professor Titular e o título de Livre-Docente continua como pré-requisito à ascensão aos degraus superiores da carreira universitária. A denominação da Faculdade passa a Faculdade de Economia e Administração da USP. Até a reforma de 1969, o Departamento de Contabilidade teve como chefes os Profs. Francisco D’Áuria, Attilio Amatuzzi, Milton Improta e José da Costa Boucinhas. Também, passam a ser estruturados os cursos de Pós-Graduação da Faculdade em nível de mestrado e doutorado.

A reestruturação de 1969 trouxe em seu esteio o reconhecimento do curso de Graduação em Contabilidade da FEA como o mais bem sucedido dentre os oferecidos pela escola. No período de 1969 a 1979, era o curso que apresentava o maior retorno de investimento em educação, conforme pesquisa realizada pela Fundação Instituto de Pesquisas Econômicas (Fipe), com os graduados obtendo colocações rápidas no mercado e a demanda no vestibular crescendo $20 \%$ ao ano. Em 1977, as 60 vagas eram disputadas por 800 candidatos, 13,33 candidatos por vaga e, em 1981, as 90 vagas foram disputadas por 2.000 candidatos, passando a 22,22 candidatos por vaga. Nesse momento, em que o país passava por um rápido crescimento, o contador e o "controller" passaram a ser profissões valorizadas no mercado.

Logo após a reforma universitária, alguns fatos marcantes tiveram lugar na FEA: a criação, em abril de 1970, da Comissão de Pós-Graduação da FEA - CPG, de acordo com o disposto no artigo $7^{\circ}$. da Portaria GR-885 de 25/08/1969, com membros dos três departamentos e do corpo discente; a implantação do mestrado em Contabilidade no segundo semestre de 1970, já no novo formato preconizado pelo Parecer 977/65, autorizado em 30/09/1970 juntamente com os mestrados em Economia e Administração; a alteração no sistema de doutoramento dos cursos de Economia e Administração, também para nova formatação; a mudança para o campus da Cidade Universitária Armando de Salles Oliveira (Cuaso), em 1971. 
O regulamento dos cursos de Pós-Graduação da FEA/ USP, adaptado ao Parecer $n^{\circ}$. 977/65 do Conselho Federal de Educação, foi aprovado pela Portaria nº 1.164 de 29/04/1970, durante a reitoria de Miguel Reale logo após a criação e implementação da Pós-Graduação pela Universidade de São Paulo, em 1969. Constituiram-se como pressupostos e requisitos do regime, dentre outros, os seguintes: dois níveis de formação, mestrado e doutorado, com o grau de mestre não se constituindo em requisito obrigatório para obtenção do título de doutor e com a duração mínima de um e dois anos, respectivamente; escolha do orientador, pelo aluno, de uma relação de docentes organizada anualmente pela CPG, cabendo-lhe a incumbência de fixar o programa de estudos do candidato; desenvolvimento das atividades escolares expressas em unidades de crédito; elaboração de trabalho, ou dissertação, a critério do departamento e da CPG, pelo candidato ao título de mestre e de tese com base em investigação original ao candidato ao grau de doutor, e submissão a uma comissão julgadora composta por três e cinco membros, respectivamente; créditos obtidos em disciplinas com prazo máximo de três e quatro anos para o mestrado e doutorado, respectivamente; submissão à comissão examinadora designada, ao exame geral de qualificação, após término dos créditos correspondentes às disciplinas, constituído de provas escrita e oral; matrícula do candidato ao curso de pós-graduação dependente da apresentação de diploma de curso superior, exame do currículo escolar e da verificação de aptidão por meio de entrevista ou prova, a critério do departamento, e prova de proficiência em uma língua estrangeira para o mestrado e duas para o doutorado. Foi assegurado, aos candidatos inscritos no doutoramento até 31/12/1969, o direito de concluir o processo de acordo com a legislação anterior, no prazo de três anos. "Quando houve a reforma universitária os que estavam inscritos tinham um prazo para entregar a tese e terminar o doutoramento até 31 de dezembro de 1972." (Professor Eliseu Martins).

O novo sistema de pós-graduação foi implantado no Departamento de Contabilidade e Atuária em 1970, com a mesma filosofia que ainda impera: formação de professores e pesquisadores e preparação de pessoal altamente qualificado para o exercício profissional. Inicialmente, apenas em nível de mestrado, contando com oito professores com título de doutor e mais cinco em processo de doutoramento. Até então, a pós-graduação no departamento existia apenas em nível de doutoramento, no chamado "formato antigo", sem uma política estabelecida pelos órgãos governamentais, assim como em todo o país: sem a existência de cursos ou disciplinas oferecidas; sendo incumbência do orientador aceitar o candidato, sugerir a aceitação da sua inscrição e oferecer disciplinas da sua responsabilidade e indicando outras cátedras para as disciplinas subsidiárias; sem classes ou aulas; com professores utilizando diferentes metodologias para diferentes candidatos. O Professor Eliseu Martins relembra o processo do seu doutoramento:

Você tinha que se inscrever e a sua inscrição tinha que ser aceita pela Congregação da Universidade, era um processo totalmente individual. Você chegava e dizia: eu quero me inscrever para fazer o doutoramento. [...] A congregação poderia rejeitar o pedido de doutoramento sem dar explicação, porque você não tinha perfil, não tinha comportamento, era muito pessoal, subjetivo, obviamente. Você também tinha o problema de cercear alguns que poderiam ser desses profissionais que estudam, capazes, mas que no fundo, na sala de aula não se sairiam bem. Mas, em compensação, podia brecar por causa de problemas pessoais ou poderia dar um empurrão para o lado e botar para dentro apadrinhados de alguns que tinham fortes poderes de convencimento no colegiado. Então, nem o sistema antigo, nem o de hoje, são perfeitos. Os dois têm prós e contras. Você tinha que fazer um projeto, o que você pretendia fazer, e então indicava um orientador. Aceito e nomeado o orientador, ele determinava as chamadas disciplinas subsidiárias. Eram aquelas que você deveria fazer além daquela ou daquelas que teria que fazer com o orientador. [...] Você fazia as disciplinas com o seu orientador e fazia as disciplinas subsidiárias, indicadas por ele, desde que o professor aceitasse. Isso era feito pessoalmente e individualmente. Não havia curso, havia tarefas. Por exemplo, eu fiz uma matéria subsidiária de Valor e Formação de Preços, na área da economia. A professora me deu um livro, desse tamanho aqui (gesto para demonstrar a espessura do livro) e falou assim: muito bem, hoje é dia dez de abril é terça-feira. Então dia dez de abril do ano que vem é quarta-feira. Bem, então nessa quarta-feira do ano que vem você me procura, primeiro com um resumo do livro, e daí eu vou fazer um exame com você. Durante esse período, se você tiver dúvidas, você me procura. Ela me deu três bibliografias complementares e essa era a base que eu tinha para fazer o resumo. Então eu passei o ano fazendo, não me lembro de ter ido lá perguntar alguma dúvida, eu lembro de ter tido dúvidas e ler os outros livros que ela havia me dado. [...] No dia marcado eu fui, levei o resumo, e me lembro que ela não fez a prova no mesmo dia. Ela decidiu primeiro ler meu resumo. Marcou outro dia e eu fui lá fiz a prova, prova oral, passei um tempo lá, duas, três horas, aí ela me aprovou. E eu fiz outra, a disciplina Análise de Balanços, da mesma forma, mas com exigências totalmente diferentes. Então, o doutoramento era desse jeito, centrado praticamente na tese. Você tinha que fazer uma atividade direta com o professor, o que exigia um nível de disciplina e autodidatismo muito fortes. E não existia Qualificação, ia direto para a defesa.

O processo de implantação do mestrado (pioneiro na área de Ciências Contábeis no Brasil) ocorreu no segundo semestre de 1970, após discussão entre os professores se ele, recém-criado pela Universidade de São Paulo, deveria ser implantado no Departamento de Contabilidade e Atuária de imediato, com todas as limitações existentes ou apenas quando fossem atingidas condições equivalentes 
às das melhores universidades do mundo. Na fala do Professor Eliseu Martins pode-se perceber como se desenvolveu a discussão para implantação do mestrado:

O Professor Boucinhas e o Professor Peres se digladiaram para montar esse mestrado. O Professor Boucinhas era super perfeccionista, então ele dizia: mestrado tem que ser com professores em tempo integral, com origens diferentes, escolas diferentes e alunos em tempo integral. Se não for assim não é mestrado. Ele já queria partir para o ótimo que já era o modelo que existia. O Professor Peres, altamente pragmático, argumentava que se fosse assim nunca iria chegar a hora, $e$ nós tínhamos que ter o mestrado. A maioria ganhou e fomos em frente, venceu a linha pragmática.

O primeiro mestre titulou-se em 1975, Wlademiro Standerski. Em 1976, Antonio de Loureiro Gil, Masayuki Nakagawa, Cecília Akemi Kobata Chinen, Massanori Monobe, Sérgio Rodrigues Bio e Lázaro Plácido Lisboa. Em 1977, José Rafael Guagliardi e Iran Siqueira Lima.

No intervalo entre a criação do mestrado e a titulação do primeiro mestre, especificamente no ano de 1974. foi criada oficialmente a Fundação Instituto de Pesquisas Contábeis, Atuariais e Financeiras (Fipecafi), pelos professores do Departamento de Contabilidade e Atuária, como órgão de apoio institucional a ele, tanto operacional quanto financeiro. Instituída e constituída por escritura pública em 01/08/1974 lavrada no $22^{\circ}$. Cartório de São Paulo e registrada no $1^{\circ}$ Ofício de Títulos e Documentos em 12/08/1974. Nesse mesmo ano, foi instituída a Fundação Instituto de Pesquisas Econômicas (Fipe), no Departamento de Economia. A Fundação Instituto de Administração (FIA) foi criada em 1980.

Dentre os objetivos estatutários da Fipecafi: promover cursos, simpósios, seminários, conferências e estudos visando à melhoria do ensino de Contabilidade; colaborar na organização e implementação dos cursos de pós-graduação; implementar sistemas de bolsas apoiando a formação de professores e estudantes; promover a divulgação de conhecimentos contábeis, financeiros e atuariais. Sua finalidade maior, buscar manter os melhores talentos dedicados ao ensino e pesquisa no departamento, num cenário em que a profissão, no entender do público, era considerada menos nobre que outras e a política salarial acadêmica carecia de atrativos. O Professor Lázaro Plácido Lisboa resume o papel desempenhado pela Fipecafi ao longo dos anos:

A Fipecafi desempenhou um papel fundamental na história do Programa de Pós-Graduação desse Departamento. Ninguém ia a congresso algum, ninguém sabia o que estava acontecendo no mundo. Se hoje você perguntar aos professores do Departamento o que o professor fulano de tal país está pesquisando, eles sabem. A Fundação proporciona a apresentação de trabalhos nos Estados Unidos, Polônia, e outros lugares do mundo. Então, há essa ligação, você acompanha o que o outro está fazendo, até para avaliar. Hoje percebo que nós estamos na frente da Espanha, de Portugal e da Argentina, na nossa área, e ter essa noção é realmente fundamental.

A proposta de criação do doutorado em Contabilidade só veio a acontecer em 1977, após a consolidação do mestrado, com nove mestres diplomados pelo programa e o processo de credenciamento do curso de mestrado em andamento junto ao Conselho Federal de Educação (efetivado em 1978). Apenas como comparação, o primeiro programa de doutorado em Contabilidade americano, data de 1938, na University of Illinois at Urbana - Champaign (BEDFORD, 1997, p. 21). A proposta foi feita pelo então chefe de departamento, Prof. Sérgio de ludícibus, e pelo coordenador da pós-graduação, Prof. Eliseu Martins. No dia 28/06/1977 foi encaminhada ao presidente da CPG, já devidamente aprovada pelo Conselho do Departamento em 16/06/1977. A implantação foi autorizada pela Reitoria da Universidade de São Paulo em 30/12/1977, iniciando-se no ano de 1978, não sem antes passar por um processo de comprovação de sua utilidade, conforme relata o Professor Eliseu Martins:

Quando foi feita a proposta para a criação do doutoramento, que nós fizemos o processo que foi para a reitoria, o próprio pró-reitor disse que não tinha como aprovar, porque afinal de contas pós-graduação é só onde existe possibilidade de fazer pesquisa, e Contabilidade: onde e o que tem para fazer de pesquisa? Tivemos que ouvir isso! Começamos, o Professor Sérgio e eu a procurar catálogos de universidades americanas, que eram as que nós tínhamos mais acesso. Juntamos um monte de catálogos de universidades de renome, que tinham o Ph.D. para mostrar. Foi um processo de convencimento pessoal do pró-reitor de que se fazia pesquisa sim em Contabilidade, no Brasil é que não se fazia quase nada. Foi algo muito interessante, dentro da própria Universidade de São Paulo o desconhecimento da área. A primeira investida não deu certo. O processo só andou depois, demorou três ou quatro vezes mais, porque tivemos que escrever para as universidades pedindo os prospectos, veio pelo correio. Aí ele aprovou. Isso foi a criação do doutorado.

A primeira turma de doutores titulou-se em 1985: Antonio de Loureiro Gil, Wlademiro Standerski e Natan Szuster. Até o ano de 1987, titularam-se mais seis: em 1986, Joéde da Silva Pimentel e, em 1987, Massanori Monobe, José Carlos Marion, Cecília Akemi Kobata Chinen, primeira mulher a se titular como doutora em Contabilidade (anteriormente havia sido a primeira mulher a se titular mestre em Contabilidade, em 1976), Masayuki Nakagawa e Magnus Amaral da Costa.

O programa, sob a coordenação do Professor Stephen Charles Kanitz e por sua iniciativa, passou a denominar-se Programa de Pós-Graduação em Contabilidade e Controladoria e só em 1990 passou a portar o nome de Programa de Pós-Graduação em Controladoria e Contabilidade, mesmo 
ano em que a faculdade passou a se chamar Faculdade de Economia, Administração e Contabilidade. A mudança da nomenclatura foi aprovada pelo Conselho de Pós-Graduação da USP em sessão realizada em 31/05/1989. Atualmente, denomina-se Programa de Pós-Graduação em Ciências Contábeis. A área de concentração é Controladoria e Contabilidade. É o Professor Eliseu Martins quem dá a justificativa para a mudança de nomenclatura:

O Stephen teve a idéia, a coragem e a ousadia de propor a mudança do nome. Havia um trabalho que ele tinha desenvolvido sobre o estereótipo do contador. Uma pesquisa sobre a imagem do contador. Sabemos que em marketing existem histórias que se encontram às dezenas, de produtos que simplesmente mudam a embalagem, mudam o nome para voltar a vender, então ele dizia que tinha que fazer isso com a palavra contador. Tinha que mudar o nome e desaparecer com essa palavra contador que não tinha mais salvação. Ele propunha diversos nomes: engenheiro de contas, engenheiro contábil, ou que se inventasse outro. [...] Daí ele, como coordenador do pós numa época, mudou o nome de Mestrado em Contabilidade para Mestrado em Contabilidade e Controladoria e, mais à frente, Mestrado em Controladoria e Contabilidade. A maior prova de que ele estava certo, acontecida muitos anos depois, é que nós tínhamos um curso de especialização em Contabilidade e Finanças. Esse curso foi dado pela USP durante doze, treze, quatorze anos, curso de quatrocentas e tantas horas. Como curso fechado foi um sucesso, como curso aberto foi uma lástima. Até que então resolvemos mudar o nome para MBA Controller, aí estourou. [...] Todos os produtos estão associados às suas imagens, visuais, sonoras, de boca a boca. Não mudou a qualidade, não melhorou a qualidade, não mudou nada, só mudou a cara e o foco do produto, e então estourou.

O ano de 1989 teve como marco a criação da Revista Contabilidade \& Finanças pelo Departamento de Contabilidade e Atuária, com o apoio da Fipecafi. Inicialmente, com o nome de Caderno de Estudos, que perdurou até a edição de $n^{\circ}$. 24, no ano de 2000. Até essa edição, esteve sob a coordenação geral da Professora Jacira Tudora Carastan, passando, então, ao Professor Lázaro Plácido Lisboa, que, em 2007, ainda a mantém.

O pedido de credenciamento do doutorado ao ConseIho Federal de Educação só aconteceu em 1990, já com 80 mestres (dentre eles um equatoriano e um nigeriano) e 23 doutores titulados e 12 anos de consolidação, juntamente com a renovação de credenciamento do mestrado. O coordenador do programa era o Professor Masayuki Nakagawa e a chefia do departamento novamente do Professor Sérgio de ludícibus, que assinou e encaminhou o processo para a Presidente da CPG, Profa. Dra. Ana Maria Bianchi, em 19/11/1990. Em 10/12/1990, a solicitação de recredenciamento, em nível de mestrado e do credenciamento em nível de doutorado, foi encaminhada ao Prof. Dr. Fernando
Affonso Gay da Fonseca, Presidente do Conselho Federal de Educação, pelo Reitor da Universidade de São Paulo, Roberto Leal Lobo e Silva Filho. O Professor Eliseu Martins justifica a demora na entrada do pedido de credenciamento do doutorado:

A universidade tinha, pela legislação da época, uma autonomia completa. Ela não registrava no MEC o mestrado, não registrava o doutorado, só implementava e pronto. E a gente se preocupava apenas com a avaliação que a universidade fazia. Então para que registrar no MEC? Você não tinha, não era obrigação, não tinha avaliação do MEC e até um certo ponto, a Capes não existia. Então a gente não se preocupava, não era obrigatório inclusive. A gente só foi se preocupar com isso depois quando começaram a criar as bolsas da Capes. A Capes começou a exigir: só dou bolsa para quem tiver credenciamento aqui. Foi aí que nós nos credenciamos. Nós nos credenciamos única e exclusivamente por interesse dos alunos, que precisavam de bolsa, senão, ninguém teria se preocupado, na época, em fazer credenciamento. Você vê quanto tempo funcionou sem ele.

No ano de 1993, o departamento identificou que os aprovados para o programa de mestrado eram, essencialmente, oriundos de São Paulo e que os professores dos cursos de Contabilidade das escolas públicas não conseguiam passar no processo de seleção. Criou-se, então, um curso de mestrado especial para esses professores de universidades públicas, denominado "turma de estrangeiros". Esse programa tinha como proposta criar a oportunidade para que esses professores participassem do curso de mestrado da FEA/USP. Para a implantação, foi criado um programa extra, semestral, denominado nivelamento, com o propósito de preparar esses professores para poderem cumprir o programa de mestrado propriamente dito, em igualdade de condições com os demais mestrandos do Departamento de Contabilidade e Atuária (EAC) e como uma substituição ao exame de ingresso no mestrado. Esse nivelamento era rigoroso quanto a um aproveitamento mínimo para aprovação do candidato e substituição ao processo de seleção normal de ingresso (teste Anpad, provas específicas e entrevista). O Professor Ariovaldo dos Santos comenta esse rigor:

Eu sempre entendi que esse tipo de seleção era muito mais rigoroso do que o teste Anpad, porque é muito mais desgastante. Você vai fazer seu teste Anpad num domingo, e se for reprovado e não falar com ninguém, ninguém fica sabendo. Se você vier para cá, do Piauí, do Maranhão, do Paraná, ou qualquer outro Estado e passar quatro meses dizendo que veio fazer um curso na USP e depois voltar logo em seguida todos vão cobrar. Então você tem um grau de responsabilidade muito forte. Mas, nós trouxemos essas pessoas, e nós fomos, com o tempo, aprendendo com o processo seletivo.

O processo iniciava-se com o envio de um convite às universidades públicas dos diversos Estados da Federação 
para que enviassem os currículos dos professores interessados em cursar o Mestrado em Controladoria e Contabilidade na FEA/USP. O processo de seleção baseava-se na avaliação desses currículos, mas, em princípio, optava-se pelos candidatos dos Estados que apresentassem apenas um concorrente. Na primeira turma, em 1993, os candidatos vinham como alunos não registrados, sem a matrícula na escola para o período de nivelamento. Só se tornavam alunos regularmente matriculados após o cumprimento e aprovação no nivelamento. Na segunda turma, para garantir acesso à bolsa de estudos, atendimento hospitalar, acesso ao restaurante, optou-se por matricular os candidatos já para o nivelamento. No entanto, a regra continuou a mesma, caso não fosse aprovado no nivelamento, estaria desligado do programa. As bolsas de estudo eram fornecidas parte pela Fipecafi e parte pelo Conselho Federal de Contabilidade (CFC). O Professor Ariovaldo dos Santos relata:

Até a terceira turma, mesmo que existissem algumas pessoas um pouco mais fracas, nós não precisamos pedir para ninguém voltar, ou seja, naquele período de nivelamento todos foram aprovados, mesmo que um pudesse ter um problema de Contabilidade, um outro de inglês, outro de matemática, avaliávamos todas as provas, pois eles faziam provas de todas as disciplinas. Fizemos uma avaliação geral e concluímos: dá para levar esse aluno, quer dizer, com um pouco de sacrifício pessoal dele entendemos que ele poderia conseguir levar o curso. Quando chegou na quarta turma, nós já não tivemos o mesmo sucesso, e o que isso significou? Significou o seguinte: da turma que veio para cá, nós matriculamos na escola como aluno oficial, com carteirinha, pagando bolsa, tudo normal, mas chegou em junho, constatamos que alguns dos alunos eram muito fracos, e tivemos que fazer com que quatro deles voltassem; os quatro voltaram, os quatro entenderam, e um deles falou: não vou mesmo ter condição de acompanhar, e eles reconheciam e iam embora.

Esse programa teve pleno êxito, nas cinco turmas que se iniciaram em 1993, 1997, 1999, 2002 e 2004, conforme pode ser comprovado pelo percentual de aproveitamento dos que ingressaram no mestrado e obtiveram o título e também em virtude daqueles que cursaram, ou estão cursando, o doutorado, conforme constante na Tabela $4 \boldsymbol{\nabla}$.
No entanto, na quinta turma o mesmo problema ocorrido com a quarta turma repetiu-se. Um dos alunos rebelou-se contra a decisão e, por meio de um advogado, fez uma representação à reitoria da universidade. O Professor Ariovaldo dos Santos relata o ocorrido:

A Reitoria nunca contestou o nosso processo seletivo, mas contestou nosso processo de dispensa, quando reprovamos uma aluna do Maranhão, junto com mais outros três de outros Estados. Desligamos esses quatro alunos do Programa, mas a aluna do $\mathrm{Ma}$ ranhão entrou com recurso junto à Reitoria, que respondeu o seguinte: "no regimento da Universidade não existe a previsão de dispensa do aluno dessa forma. Tem porque o aluno abandonou, porque não fez matrícula, porque o tempo dele estourou, porque ele foi reprovado três vezes na mesma disciplina, mas não era o caso". Ela não tinha sido reprovada em nenhuma disciplina, porque ela sequer estava matriculada em alguma disciplina do programa oficial do pós; ela recebeu uma matrícula pro forma, para poder fazer o curso de nivelamento, e nesse tempo receber a bolsa, a carteirinha e os benefícios de quem é aluno regular da escola. Isso significa, ela não aceitou a reprovação. Por que ela não aceitou a reprovação e o que aconteceu? Obviamente, tudo isso criou um mal estar. [...] Na carta que ela recebeu que é a carta de seleção, de convite, para que ela submetesse o currículo estava muito claro, estava lá escrito se você não for aprovado você volta, estava escrito. Mas ela falou: "isso não estava escrito, eu não entendi desse jeito, não me falaram, eu não li a carta, esse tipo de coisa". Bom, então ela ganhou. Ganhou e veio fazer o curso, e obviamente foi fazer as disciplinas obrigatórias que nós achávamos que ela teria problemas, e ela foi reprovada. Infelizmente, a reprovação não foi só dela, todo esse processo acabou reprovando também um programa que apresentou resultados nunca antes alcançados. E assim não tivemos outra alternativa a não ser a de extinguir um programa que trazia para cá professores de universidades públicas de todo país.

Assim, desde 2004, não foram mais formadas "turmas de estrangeiros" no Departamento de Contabilidade e Atuária da FEA/USP. A primeira turma foi coordenada pelo Prof. Dr. Masayuki Nakagawa, as outras quatro, pelo Prof. Dr. Ariovaldo dos Santos.

Tabela 4 Turmas de mestrado dos professores de escolas públicas - 1993 - 2004

\begin{tabular}{c|c|c|c|c} 
Turma & Início & Inscritos & Titulados & $\%$ \\
$1^{a}$ & 1993 & 11 & 10 & 91 \\
\hline $2^{a}$ & 1997 & 17 & 15 & 88 \\
\hline $3^{a}$ & 1999 & 19 & 17 & 89 \\
\hline $4^{a}$ & 2002 & 19 & 13 & 68 \\
\hline $5^{a}$ & 2004 & 15 & 9 & 60 \\
\hline Total & & $\mathbf{8 1}$ & $\mathbf{6 4}$ & $\mathbf{7 9}$
\end{tabular}

Fonte: Coordenação do programa 
No segundo semestre de 1999, iniciou-se um mestrado interinstitucional fruto de convênio entre a Universidade de São Paulo, após anuência da FEA, e as Universidades Federais do Ceará, Paraíba e Pernambuco. Iniciaram o curso 14 alunos, dos 26 candidatos que se apresentaram para o exame de seleção. Os candidatos eram, em sua maioria, professores das três universidades participantes do convênio, e por elas indicados. O processo formal de seleção envolveu aprovação no teste da Associação Nacional de Pós-Graduação e Pesquisa em Administração (Anpad), provas de conhecimentos específicos (Contabilidade Societária e Teoria da Contabilidade), análise curricular e entrevistas realizadas pelos professores doutores Diogo Toledo do Nascimento, coordenador do Programa de Pós-Graduação à época, e Lázaro Plácido Lisboa. O curso desenvolveu-se totalmente na forma presencial, nas dependências da Universidade do Ceará, ao longo de trinta meses (com mais seis meses de prorrogação aprovados pela Reitoria da Universidade de São Paulo) e titulou doze mestres. "Após a experiência, concluiu-se que, na época, a estrutura do Programa de Pós do EAC não comportava projetos daquela ordem" (Professor Diogo Toledo do Nascimento).

Esse projeto de parcerias ampliou-se e, em 13/03/2000, foi fechado um convênio entre o CFC e a Fipecafi, com a interveniência e anuência da FEA/USP, por intermédio do Departamento de Contabilidade e Atuária 4 , para a realização de cinco turmas de Mestrado em Controladoria e Contabilidade, em cinco Estados da Federação, em atendimento a demandantes por programas de mestrado ministrados parte a distância: Ceará, Minas Gerais, Santa Catarina, Mato Grosso e Pará. Dentre os objetivos específicos do convênio: formar docentes capacitados a difundir conhecimentos através de reflexão e análise crítica renovadas; formar pesquisadores de alto nível; aprimorar o corpo docente e a qualidade das pesquisas e dissertações, através de intercâmbio acadêmico com outras instituições de reconhecida experiência na área contábil; propiciar condições aos egressos de se candidatarem a programas de doutorado dentro e fora do país. A gestão do convênio foi exercida por um comitê formado por dois representantes da Fipecafi e dois do CFC. Foram identificadas e selecionadas pelos representantes do CFC, em cada Estado, instituições de ensino superior que pudessem servir como centros de apoio administrativo e pedagógico, recebendo os alunos. Também coube ao CFC $\mathrm{o}$ apoio para a implantação dos recursos inerentes às aulas por videoconferência. As normas e exigências relativas à qualidade do curso foram as mesmas estabelecidas para o Programa de Mestrado tradicional, regularmente oferecido pelo Departamento de Contabilidade e Atuária da FEA/USP, e o corpo docente formado exclusivamente por professores credenciados no programa tradicional. A seleção dos alunos para essas turmas coube aos representantes do CFC.

O convênio destinou-se, exclusivamente, a contadores com registro no Conselho Regional de Contabilidade de sua jurisdição e em pleno gozo de suas prerrogativas. O critério adotado para o processo de seleção, 25 ingressantes em cada Estado, foi análise curricular e entrevistas. Da mesma forma que no mestrado de professores de instituições públicas, a primeira etapa do mestrado consistiu em um programa de nivelamento realizado durante quatro meses, também em substituição ao processo de seleção tradicional. Os candidatos selecionados foram inscritos no programa como alunos especiais, tanto no estágio do nivelamento como no curso, e assim permaneceram até o momento do exame de qualificação, quando passaram à condição de alunos regulares. Foram dez as disciplinas oferecidas e cursadas pelos alunos durante o curso, parte presencial e parte a distância. Além de integralizar 80 créditos, obter proficiência em inglês, passar pelo exame de qualificação e apresentar dissertação, o programa exigia dos alunos um estágio presencial no Departamento de Contabilidade e Atuária na Cidade Universitária, sede da USP em São Paulo de, no mínimo, 45 dias, para finalização das dissertações. O convênio vigorou pelo prazo de 4 anos. As estatísticas referentes a essas cinco turmas estão na Tabela $5 \mathbf{0 .}$

Tabela 5 \Convênio CFC x Fipecafi - FEAJUSP

\begin{tabular}{l|c|c|c|c|c|c} 
Estado & CE & MG & SC & MT & PA & Total \\
Início & $2000 / 1$ & $2000 / 1$ & $2000 / 2$ & $2000 / 2$ & $2001 / 1$ & \\
\hline Instituição de apoio & UNIFOR* & UNA** $^{*}$ & UNIVALE*** & UNIRONDON*** & UNAMA**** & \\
\hline Ingressantes no nivelamento & 25 & 25 & 25 & 25 & 25 & 125 \\
\hline Ingressantes no mestrado & 23 & 24 & 21 & 24 & 20 & 112 \\
\hline $\begin{array}{l}\text { Entregaram dissertação para } \\
\text { qualificação }\end{array}$ & 22 & 14 & 16 & 14 & 13 & 79 \\
\hline Entregaram dissertação para defesa & 21 & 14 & 16 & 14 & 12 & 77 \\
\hline Total de mestres & 20 & 14 & 16 & 14 & 11 & 75
\end{tabular}

*Fundação Edson Queiroz; **União de Negócios e Administração; ***Universidade Vale do Itajaí;

****Faculdades Integradas Cândido Rondon; *****Universidade da Amazônia

Fonte: Fipecafi, 2007

4 Baseado em Jacomini (2003), na experiência vivenciada pela autora, participante da turma do Estado de Minas Gerais e no documento formal do Convênio para desenvolvimento de Programa de Mestrado em Controladoria e Contabilidade, fechado entre as partes. 
Com o objetivo de se constituir num espaço de apresentação e discussão de trabalhos, o Departamento de Contabilidade e Atuária e a Fipecafi lançam, em 2001, o $1^{\circ}$. Seminário USP de Controladoria e Contabilidade, sob a coordenação geral do Prof. Dr. Gilberto de Andrade Martins, que também foi seu idealizador. No ano de 2003, elevou-se ao status de Congresso e passou a contar com um evento específico para alunos de graduação, o Congresso USP de Iniciação Científica. Em 2007, os eventos estão em sua $7^{\mathrm{a}}$ e $4^{\mathrm{a}}$ edições, respectivamente, sob a coordenação geral do Prof. Dr. Welington Rocha.

O programa tem construído seu desenvolvimento, apesar de todas as dificuldades. No último relatório de avaliação do Programa de Pós-Graduação em Ciências Contábeis, relativo ao triênio de avaliação 2001/2003 divulgado em setembro de 2004, a Capes considerou a proposta do programa adequada, merecendo avaliação global muito boa e conceito 5 .

Este Programa possui o único Doutorado em Contabilidade e Controladoria do país e evoluiu significativamente nos principais quesitos da avaliação ao longo do triênio, com destaque para a produção intelectual, teses e dissertações e corpo discente. Cabe destacar também que, relativamente à avaliação do triênio anterior, quando seu conceito foi reduzido de 4 para 3 , houve melhora em todos os quesitos da avaliação, tendo atingido um nível de desempenho compatível com o conceito 5 da área básica de Ciências Contábeis (Justificativa da comissão responsável pela avaliação).

Nos quesitos corpo discente, teses e dissertações e produção intelectual, a melhora foi considerada forte. Alguns problemas foram identificados: a falta de bolsistas recém-doutores, a presença de um único professor visitante (em 2002), a distribuição dos projetos entre as linhas de pesquisa, o número elevado de desligamentos no mestrado ao longo do triênio e no doutorado em 2003, a participação dos discentes nos projetos de pesquisa do programa foi considerada muito boa, no entanto, não se refletiu de maneira sistemática em produção discente, colocando em dúvida a qualidade dessa participação. A única recomendação feita pela comissão foi quanto à melhoria na distribuição da produção científica entre os docentes do NRD6 ${ }^{5}$, principalmente em periódicos.

As avaliações da Capes são vistas como positivas dentro do Departamento de Contabilidade e Atuária. O Professor Eliseu Martins é um dos defensores:

Eu sempre fui muito favorável à avaliação. Todos nós somos avaliados e avaliamos regularmente. $\mathrm{O}$ que é importante é você se instrumentalizar e formar mecanismos de instituição e mecanismos de avaliação. Um instrumento de avaliação bem dirigido é fantástico, mal dirigido é uma lástima. E o saldo da existência da Capes, no que diz respeito aos programas de maneira geral, não só na nossa área, é bom e acho que nós só estamos aqui conversando por causa disso.

Mas também foram observados pontos negativos nelas. Conforme relatos dos Professores Sérgio de ludícibus e Eliseu Martins, respectivamente:

As poucas referências negativas com relação aos critérios da Capes referem-se, talvez, à falta de consideração de algumas peculiaridades dos contadores, dos cursos de contábeis e dos professores da área contábil. Eles insistem (a Capes) muito em um mundo ideal de uma universidade norte-americana em que professores e alunos são de tempo integral e em que professores ganham, em média, doze mil dólares por mês. Está muito longe da nossa realidade. Mas, também, eu não sei se esta imposição de algo que para nós ainda é uma utopia, no fundo não faz com que tentemos melhorar a qualidade. Porque é muito fácil a gente se acomodar, fazer um pacto de não qualidade entre alunos e professores. Uma boa faculdade, de nível internacional, precisaria ter a maior parte dos alunos e de seus professores em tempo integral. Esses últimos podendo viver de seus salários, sem precisar, mesmo que amparados pela legislação, se "desviarem", dando aulas adicionais em cursos vários, para poder complementar suas remunerações, não sobrando tempo para realizar pesquisas e escrever artigos de qualidade internacional.

O que acontece é que a Capes trabalha com um instrumental quantitativo. E isso é sempre problemático. Então eu reconheço que ela pode, às vezes, estar falhando, mas acho que poderíamos estar no meio de uma bagunça sem a Capes. E teria muita gente se aproveitando disso por aí.

No entanto, o departamento sabe reconhecer que existem muitos pontos fracos no programa, como também pontos fortes. Dentre os pontos fracos identificados pelos entrevistados: a endogenia (atribuída à existência de apenas um programa de doutorado em Contabilidade); o envelhecimento do departamento sem perspectiva de substituição; a acomodação (também atribuída ao único doutorado); a dificuldade de unidade e de articulação entre os professores, significando um conjunto de professores conversando mais sobre o programa, sabendo para aonde vai; o resquício das cátedras com professores "donos das disciplinas"; o conservadorismo que provoca estagnação e letargia, falta de uma instituição ou ação que cuide da qualidade da produção (da qualidade das dissertações e teses produzidas); a ansiedade por pontos na Capes; o formato do processo de admissão, considerado com uma dose de subjetivismo muito grande na escolha dos candidatos. Como pontos fortes: a lealdade e comprometimento dos docentes ao departamento; o preparo e nível de atualização dos docentes; o fato de ser desenvolvido em uma uni-

5 Núcleo de Referência Docente (NRD) - fração do corpo docente que assegura caracterização institucional e continuidade às atividades do programa. A maior referência é o NRD6. 
versidade pública, gratuito, sem dono; a tradição; o fato de o programa não ser tão experimental.

Comparativamente ao passado, o programa hoje se encontra num momento único. "O programa está vivendo um momento extremamente importante, porque existe uma preocupação de internacionalização e ao mesmo tempo acomodação" (Professor Fábio Frezatti). A estabilização é um ponto comum nas observações do ex e do atual coordenador do programa, Professor Gilberto de Andrade Martins:

O programa tem um estágio interessante, passou por uma fase ruim, com uma nota baixa da Capes e, como fruto de um esforço muito forte do Fábio e de todos os professores ele acabou chegando nesse estágio de nota cinco. Eu quero registrar o seguinte, na verdade, o esforço de passar de três para cinco foi muito interessante. Mas, eu percebo que acabou aquele entusiasmo, aquela preocupação acabou assim que obteve a nota cinco. Aí relaxou, ficou meio parado, continua fazendo, eu diria para o gasto, nada excepcional, mas o patamar já com cinco, um pouco devagar, mas está caminhando. Na realidade, o programa de pós-graduação nunca está pronto, nunca está completo, está sempre em construção.

As perspectivas para o futuro são boas, mas vistas também com alguma inquietação, conforme se observa pela fala do Professor Gilberto de Andrade Martins e, na seqüência, do Professor Sérgio de ludícibus:

Minha preocupação, agora como coordenador, é agregar mais colegas professores para o curso. Tenho conversado com o pessoal da Economia e da Administração para trazer professores convidados deles para cá. Como perspectiva para o programa de pós-graduação, acho que vamos conseguir caminhar, ou seja, um programa mais arejado, mais dinâmico, mais democrático, que é uma palavra que parece às vezes ofensiva para algumas pessoas, mas à medida que ele se democratiza, que ele coloca suas mazelas um pouco mais a mostra, as coisas começam a caminhar de uma maneira muito mais interessante. Um fato que parece acessório, mas é muito colado ao programa, é o congresso. E esse evento tem que colar mais ainda ao programa.

Então, eu vejo com alguma inquietação o futuro sim. Não sou tão otimista porque, lamentavelmente, sob o ponto de vista estrutural, a Universidade de São Paulo não se aparelhou para enfrentar os tempos modernos, ela depende demais das verbas do orçamento do Estado [...]. Assim, há motivos para ser otimista? Em nível latino-americano sim, mas se compararmos com as grandes universidades internacionais há uma inquietação muito grande de minha parte com relação ao futuro. [...] Lamentavelmente, o mercado tira talentos brilhantes da academia na fase mais produtiva deles. Eles ingressam depois, aos poucos, para a atividade docente (em faculdades profissionalizantes, tipo FEA, como ex-executivos de empresas), mas já em uma idade avançada. E, de maneira geral, depois dos 40 anos, essa força propulsora de pesquisas, de mudança radical, até revolucionária, que às vezes o pesquisador precisa ter, já não é, na média, uma tendência da maioria das pessoas. Eles tendem a consagrar o "estado da arte", sem a criatividade e os desafios do pesquisador mais jovem. Ainda bem que em faculdades como a FEA existem as Fundações de apoio aos departamentos que, em parte, mitigam os problemas analisados.

E o caminho a seguir é longo na perspectiva do Professor Eliseu Martins:

Eu acho que o nosso doutoramento ainda está um pouco distante dos bons doutoramentos. Em parte porque somos uma leva, a maioria dos professores, muito da velha guarda. Não estamos, eu sou o primeiro a reconhecer, preparados para isso, numa relação de faixa etária até meio difícil de se adaptar. Então você tem que confiar muito nos mais jovens que vêm aí. Os doutoramentos hoje no exterior exigem um volume de pesquisa e dedicação ao estudo muito mais pesado do que o nosso, mas o nosso melhorou muito.

A busca pela superação dos pontos fracos e a manutenção dos pontos fortes, além do comprometimento do programa com seu papel social, podem ser identificados pela proposta, apresentada por ocasião do preenchimento da coleta de dados para a Capes referente ao ano base de 2006, em que constam como objetivos do programa:

- Possibilitar e garantir uma formação global e crítica de docentes e pesquisadores capacitados para o exercício da cidadania, formação profissional e pleno desenvolvimento pessoal por meio de um projeto político-pedagógico, discutido e analisado por docentes, pesquisadores e discentes, em sintonia com uma nova visão de mundo;

- Continuar a oferecer apoio técnico-científico para a edição da Revista Contabilidade E Finanças e para a Coordenação e Comitê Científico do Congresso USP de Controladoria e Contabilidade;

- Compor as equipes de pesquisa, consultoria e assessoria dos Laboratórios e Centros de Estudos do departamento;

- Estabelecer parcerias com entidades afins, bem como colaborar para que programas nacionais de pós-graduação do campo das Ciências Contábeis aperfeiçoem suas ofertas de cursos e pesquisas científicas.

\subsubsection{Estatísticas dos Programas de Pós-Graduação da FEAVUSP}

De acordo com a Secretaria de Pós-Graduação da FEA/ USP, no período de 1958 a 2005, a FEA, nos seus três departamentos, titulou 1.554 mestres e 705 doutores. Comparativamente, Hasselback ${ }^{6}$ (2007) identifica, até 08/06/2007. 
mais de 6.500 titulados apenas pelos programas americanos que oferecem doutorado em Contabilidade ou com concentração em Contabilidade. O Departamento de Economia foi o primeiro a produzir tanto uma dissertação de mestrado, quanto uma tese de doutorado, em 1972 e 1958, respectivamente. Da Tabela 60 constam os números de mestres e doutores titulados nos Departamentos de Economia e Administração. No período, o Departamento de Economia titulou 431 mestres e 230 doutores. O ano de 2003 foi aquele em que se titularam mais mestres, 33, e os anos de 1973 e 1994 estão à frente no número de doutores, 14 em cada um deles. As décadas de 1990 e 2000 produziram mais da metade dos mestres e doutores em Economia.

No Departamento de Administração, titularam-se 699 mestres e 320 doutores. O primeiro mestre titulou-se em 1973 e o primeiro doutor em 1970. Coincidentemente, o ano de 2003 foi aquele em que se titularam mais mestres nesse departamento, 83. O maior número de doutores em Administração formou-se em 2004, em número de 39. Mais da metade dos mestres em Administração titularam-se na década de 2000 e quase $44 \%$ dos doutores também.

No Departamento de Contabilidade e Atuária, a primeira dissertação de mestrado foi defendida em 1975. Foram 424 ao todo. Mais da metade dos mestres obtiveram seu título na década de 2000, sendo o ano de 2003 o responsável pelo maior número deles, 69. O programa de professores das universidades públicas foi responsável por 64 títulos, o mestrado interinstitucional realizado com as Universidades Federais do Ceará, Paraíba e Pernambuco,
12, e o mestrado resultante do convênio com o CFC, 75 (Tabela $7 \mathbf{0}$ ).

Desde 1962, quando a primeira tese de doutorado foi defendida pelo Professor Hirondel Simões Luders, até 31/12/2005, foram defendidas, no Departamento de Contabilidade e Atuária, 159 teses de doutorado. Esse número cai para 147, quando consideradas aquelas defendidas conforme a formatação atual da pós-graduação. Na Tabela 80 , o número de teses defendidas a cada ano.

Observe-se que mais de $50 \%$ das teses de doutorado foram defendidas nos últimos seis anos do programa, ou seja, na década de 2000, em número de 81 . O ano de 2000 foi o recordista no número de defesas, 19, e, desde 1985, o único ano em que não houve defesa foi 1992. Constate-se, ainda, que não há um padrão no número de defesas, seja ele crescente ou decrescente. Cinco dos doutores titulados são oriundos do programa de professores de universidades públicas. Ressalte-se que, no primeiro semestre de 2007 , havia 5 mestres titulados nesse mesmo programa cursando o Doutorado em Ciências Contábeis, além de 4 outros mestres oriundos do mestrado fruto do convênio com o CFC.

De acordo com os dados constantes do Sistema Fênix - Sistema de Pós-Graduação, de 02/01/1984 a 23/11/2006 (respectivamente, data em que se iniciou o controle e data em que os dados foram coletados junto à Secretaria da PósGraduação), podem-se estabelecer algumas estatísticas relativas ao programa e ao Doutorado em Ciências Contábeis:

- Número de alunos ingressantes no Programa de Pós-Graduação no período: 1.032;

Tabela 6 || Mestres e doutores em Economia e Administração - 1950-2005

\begin{tabular}{l|c|c|c|c}
\multirow{2}{*}{ Período } & \multicolumn{2}{|c|}{ Economia } & \multicolumn{2}{c}{ Administração } \\
\cline { 2 - 5 } & Doutores & Mestres & Doutores & Mestres \\
\hline $1950-1959$ & 1 & & & \\
\hline $1960-1969$ & 10 & & & \\
\hline $1970-1979$ & 21 & 63 & 19 & 28 \\
\hline $1980-1989$ & 60 & 104 & 58 & 103 \\
\hline $1990-1999$ & 89 & 118 & 103 & 218 \\
\hline $2000-2005$ & 49 & 146 & 140 & 350 \\
\hline Total & $\mathbf{2 3 0}$ & $\mathbf{4 3 1}$ & $\mathbf{3 2 0}$ & $\mathbf{6 9 9}$
\end{tabular}

Fonte: Secretaria de Pós-Graduação da FEA/USP

Tabela 7 | Mestres em Ciências Contábeis - 1975-2005

\begin{tabular}{c|c|c|c|c|c|c|c} 
Período & Mestres & Período & Mestres & Período & Mestres & Período & Mestres \\
1975 & 1 & 1985 & 5 & 1993 & 6 & 2001 & 25 \\
\hline 1976 & 7 & 1986 & 2 & 1994 & 11 & 2002 & 43 \\
\hline 1977 & 1 & 1987 & 3 & 1995 & 14 & 2003 & 69 \\
\hline 1980 & 4 & 1988 & 2 & 1996 & 16 & 2004 & 47 \\
\hline 1981 & 16 & 1989 & 9 & 1997 & 9 & 2005 & 24 \\
\hline 1982 & 9 & 1990 & 7 & 1998 & 17 & & \\
\hline 1983 & 9 & 1991 & 13 & 1999 & 14 & & \\
\hline 1984 & 7 & 1992 & 7 & 2000 & 27 & TOTAL & $\mathbf{4 2 4}$
\end{tabular}

Fonte: Secretaria de Pós-Graduação da FEAJUSP 
Tabela 8 || Doutores em Ciências Contábeis - 1962-2005

\begin{tabular}{c|c|c|c|c|c|c|c} 
Período & Doutores & Período & Doutores & Período & Doutores & Período & Doutores \\
\hline 1962 & 1 & 1986 & 1 & 1993 & 7 & 2000 & 19 \\
\hline 1965 & 1 & 1987 & 5 & 1994 & 4 & 2001 & 14 \\
\hline 1966 & 2 & 1988 & 7 & 1995 & 4 & 2002 & 13 \\
\hline 1967 & 1 & 1989 & 3 & 1996 & 9 & 2003 & 11 \\
\hline 1968 & 1 & 1990 & 7 & 1997 & 3 & 2004 & 7 \\
\hline 1973 & 6 & 1991 & 1 & 1998 & 5 & 2005 & 17 \\
\hline 1985 & 3 & 1992 & 0 & 1999 & 7 & TOTAL & $\mathbf{1 5 9}$
\end{tabular}

Fonte: Secretaria de Pós-Graduação da FEAJUSP

- Número de alunos ingressantes no curso de mestrado: 805:

- Número de alunos ingressantes no curso de doutorado: 227;

- Número de alunos desligados do curso de doutorado sem conclusão: 40;

- Número de alunos do curso de doutorado com créditos concluídos em processo de elaboração de tese: 31 ;

- Número de alunos regularmente matriculados no curso de doutorado, cursando créditos: 9;

- Número de alunos que foram transferidos diretamente do curso de mestrado para o curso de doutorado: 16.
Cabe observar o número expressivo de desligamentos do doutorado sem a conclusão do curso: $17,62 \%$ dos ingressantes. Comparado com o percentual americano, em que cerca de $50 \%$ dos matriculados no doutorado em todas as áreas nunca obtêm o título (VELHO, 1998, p. 85), podese até considerá-lo baixo. Ainda no ano de 2006 titularamse na FEA mais 80 mestres: 38 em Administração, 22 em Economia e 20 em Ciências Contábeis; e 42 doutores: 27 em Administração, 9 em Economia e 6 em Ciências Contábeis. À época da elaboração deste estudo, um processo de seleção encontrava-se em andamento.

\section{CONSIDERACÕ̃ES FINAIS}

O propósito principal desta pesquisa foi resgatar a história do Programa de Pós-Graduação do Departamento de Contabilidade e Atuária da Faculdade de Economia Administração e Contabilidade da Universidade de São Paulo.

Os achados da pesquisa permitem concluir que esse programa nasceu, principalmente, da vontade, necessidade e perseverança dos professores vinculados ao departamento. Hoje se encontra consolidado, mesmo que, conforme observado por sua própria coordenação, em processo de constante construção.

Infelizmente, o que se percebeu foi que a evolução dos Programas de Pós-Graduação Stricto Sensu em Ciências Contábeis não acompanhou a evolução desses mesmos programas em outras áreas do conhecimento. E, talvez, esse se constitua num ponto de inquietação.

Entende-se que um aspecto negativo para a evolução do Programa de Pós-Graduação do Departamento de Con- tabilidade e Atuária da Faculdade de Economia Administração e Contabilidade da Universidade de São Paulo tenha sido o seu desenvolvimento sem concorrentes quando se fala do doutoramento e, durante um extenso período, também no mestrado.

Constatou-se que uma grande preocupação dos responsáveis e idealizadores do programa é com sua continuidade e aperfeiçoamento, cuidando pela qualidade da pesquisa produzida em suas dependências, que em termos quantitativos, também não possui concorrentes.

Sem dúvida, o corpo docente é o ponto mais forte do programa, reconhecimento esse, feito pelos próprios pares. Observou-se, no entanto, que a endogenia é um fator preocupante e o ponto mais fraco. 


\section{Referências}

ALVES, D. C. O. A reforma universitária da Universidade de São Paulo. In: CANABRAVA, A. P. (Org.). História da Faculdade de Economia e Administração da Universidade de São Paulo. Editor: Prof. Dr. José Augusto Guagliardi, São Paulo, v. 1, p. 113-123, 1984.

ANUATTI NETO, F. Competição e complementaridade dos centros de pós-graduação em economia. In: LOUREIRO, M. R. (Org.). 50 anos de Ciência Econômica no Brasil (1946-1996): pensamento, instituições, depoimentos. Petrópolis, RJ: Vozes, 1997. p. 183-201.

BEDFORD, N. M. A history of accountancy at the University of Illinois at Urbana-Champaign. Center for International Education and Research in Accounting, Champaign, IL, 1997.

BEIGUELMAN, B. Reflexões sobre a pós-graduação brasileira. In: PALATINIK et al. (Org.). A pós-graduação no Brasil. Rio de Janeiro: Universidade Federal do Rio de Janeiro, 1998. p. 33-48.

BOWEN, N. R. Attitudes and opinions regarding the dissertation process at the Chicago School of professional psychology. Chicago, 2004. Dissertation (Doctor of Psychology) - Faculty of the Chicago School, 2004. UMI Number: 3135707.

BRASIL. CESu/CFE. Parecer 977 de 03 de dezembro de 1965. Diário Oficial da União: 20/01/1966. Brasília, DF, 1965.

BRASIL. CFE. Parecer 77 de 1969. Publicado em 11 de fevereiro de 1969, Documenta, Brasília, DF, n. 98; p. 128-132, 1969.

BRASIL. Congresso Nacional. Lei 5.540 de 28 de novembro de 1968. Diário Oficial da União: Brasília, DF, 1968.

BRASIL. Ministério da Educação e Saúde Pública. Decreto 19.851 de 11 de abril de 1931. Estatuto das Universidades Brasileiras. [S.l., s.n.]. BRASIL. Presidência da República. Lei 9.394 de 20 de dezembro de 1996. Diário Oficial da União: 23/12/1996. Brasília, DF, 1996.

BUCHANAN, A. L.; HERUBEL, J. P. V. M. The Doctor of Philosophy degree: a selective annotated bibliography. Westport, CT/London: Greenwood Press, 1995.

CANABRAVA, A. P. (Coord.). História da Faculdade de Economia e Administração da Universidade de São Paulo 1946-1981. Volumes 1 e 2. Editor: José Augusto Guagliardi, São Paulo: FEA/USP, 1984.

CHUBIN, D. E.; ROBINSON, E. M. Human resources for the research work force: US indicator and policy choices. Science and Public Policy, London, v. 9, n. 6, p. 334-342, 1992

CLARK, W. On the Ironic Specimen of the Doctor of Philosophy. Science in Context, Great Britain, v. 5, n. 1, p. 97-137, 1992.

COORDENAÇÃO DE APERFEIÇOAMENTO DE PESSOAL DE NÍVEL SUPERIOR - CAPES. Plano Nacional de Pós-Graduação (PNPG) -2005-2010. Brasília, 2004. Disponível em: <http://www.capes.gov.br/capes/portal/conteudo/10/PNPG.htm>. Acesso em: 25 jan. 2006.

COORDENAÇÃO DE APERFEIÇOAMENTO DE PESSOAL DE NÍVEL SUPERIOR - CAPES. Estatísticas da pós-graduação. Disponível em: $<$ http://www.capes.gov.br/capes/portal/conteudo/10/EstatisticasPG.htm>. Acesso em: 08 set. 2006a.

COORDENAĈ̃̃O DE APERFEICOAMENTO DE PESSOAL DE NÍVEL SUPERIOR - CAPES. Conheca a CAPES. Disponível em: <http:// www.capes.gov.br/capes/portal/>. Acesso em: 31 ago. 2006b.

COORDENAÇÃO DE APERFEIÇOAMENTO DE PESSOAL DE NÍVEL SUPERIOR - CAPES. Avaliação. Disponível em: <http://www.capes. gov.br/capes/portal/>. Acesso em: 30 ago. 2006c.

CURY, C. R. J. Quadragésimo ano do parecer CFE n. 977/65. Revista Brasileira de Educação, Belo Horizonte, n. 30, p. 7-20, 2005.

EIDMANN, B. C. An analysis of educational leadership doctoral programs offered in California Universities. Dissertation for the degree Doctor of Education. University of La Verne, 2002, UMI Number: 3060175.

ENGEL, M. Thesis-antithesis: reflections on the education of researchers in psychology. American Psychologist, Washington, v. 21, n. 8, p. $781-787,1966$

FACULDADE DE ECONOMIA, ADMINISTRAÇÃO E CONTABILIDADE - FEA/USP. Disponível em: <http://www.erudito.fea.usp. br/portalfea/>. Acesso em: 2007.

FACULDADE DE ECONOMIA, ADMINISTRAÇ̃̃O E CONTABILIDADE - FEA/USP. Comemorativo dos 60 anos. Disponível em: <http:// www.fea60anos.com.br/>. Acesso em: 17 abr. 2007.

FACULDADE DE ECONOMIA, ADMINISTRAÇÃO E CONTABILIDADE - FEA/USP. Programa de Pós-Graduação em Controladoria e Contabilidade. Folheto Informativo (Comemorativo dos 25 anos da FEA). São Paulo: [s.n.], 2002.

FUNDAÇÃO DE AMPARO A PESQUISA DO ESTADO DE SÃO PAULO - FAPESP. Indicadores de ciência, tecnologia e inovação em São Paulo - 2001. Disponível em: <http://www.fapesp.br/indct/>. Acesso em: 13 fev. 2006.

GALL, M. D.; GALL, J. P.; BORG, W. R. Educational research: an introduction. 8. ed. Person/Allyn and Bacon, 2007.

GOODCHILD, L.; MILLER, M. M. The american doctorate and dissertation: six developmental stages. New Directions for Higher Education, v. 25, n. 3, p. 17-32, 1997.

GRACELLI, A.; CASTRO, C. M. O desenvolvimento da pós-graduação no Brasil. São Paulo: Ciência e Cultura, v. 37, n. 7, suplemento, p. 188201, 1985.

GUIMARÃES, R. Pesquisa no Brasil: a reforma tardia. São Paulo em Perspectiva, v. 16, n. 4, p. 41-47, 2002. Disponível em: <http://www.cgee org.br/parcerias.php>. Acesso em: 12 jan. 2006.

GUIMARÃES, R.; CARUSO, N. Capacitação docente: o lado escuro da pós-graduação. Notas sobre o Estado da Arte e Elementos para uma Política. INFOCAPES - Boletim Informativo, Brasília, v. 4, n. 3, p. 7-18, 1996.

HASSELBACK, J. R. Website. Disponível em: <http://www.jrhasselback.com/>. Acesso em: 03 fev. 2007. 
INSTITUTO NACIONAL DE ESTUDOS E PESQUISAS EDUCACIONAIS ANISIO TEIXEIRA - INEP. EDUTABRASIL. Sistema de Estatísticas Educacionais. Disponível em: <http://www.edudatabrasil.inep.gov.br/>. Acesso em: 30 jan. 2006.

JACOMINI, D. D. A biblioteca universitária e a educação a distância: um estudo de caso na FEA/USP. São Paulo, 2003. Dissertação (Mestrado em Biblioteconomia e Documentação) - Escola de Comunicações e Artes da Universidade de São Paulo - ECA/USP, 2003.

MARCHELLI, P. S. Formação de doutores no Brasil e no mundo: algumas comparações. RBPG, v. 2, n. 3, p. 7-29, mar. 2005. Disponível em: $<$ http://www.capes.gov.br/rbpg/portal>. Acesso em: 15 maio 2006.

MARTINS, A. C. P. Ensino superior no Brasil: da descoberta aos dias atuais. Acta Cirúrgica Brasileira, São Paulo, v. 17 (suplemento 3), 2002, Disponível em: $<$ http://www.scielo.br/scielo.php?script=sci_arttext\&pid=S0102-86502002000900001\&lng=es\&nrm=isso $>$. Acesso em: 30 ago. 2006.

MARTINS, G. A.; SERRA, R. M. R. Pós-graduação em Administração: quem são os candidatos? In: SEMEAD - SEMINÁRIOS EM ADMINISTRAÇÃO, 3.,1998, São Paulo, Anais... São Paulo: 1998.

PARK, C. New variant PhD: the changing nature of the doctorate in UK. Journal of Higher Education Policy and Management, Abingdon, v. 27, n. 2, p. 189-207, july 2005.

PINHO, D. B. A FEA-USP no tempo: contribuição à memória de seus 60 anos. São Paulo: FEA/USP, 2006.

SCHATTE, C. E. The persisting European heritage of the American Ph.D. Improving College and University Teaching, v. 25, n. 2, p. 75-8, 81, 1977.

SCHWARTZMAN, S. A Universidade de São Paulo e a questão universitária no Brasil. [S.d.] Disponível em: <http://www.schwartzman.org. br/simon/usp70.htm>. Acesso em: 06 set. 2006.

SELLTIZ, C. et al. Métodos de pesquisa nas relações sociais. Tradução de Dante Moreira Leite. 6. ed. São Paulo: E.P.U., 1967.

SIMPSON, R. How the PhD came to Britain: a century of struggle for postgraduate education. Guildford, Surrey: Society for Research into Higher Education, 1983.

SOCIEDADE BRASILEIRA PARA O PROGRESSO DA CIÊNCIA - SBPC. Institucional - História. Disponível em: <http://www.sbpcnet.org. br/sobre/historia.htm>. Acesso em: 30 ago. 2006.

SPAGNOLO, F.; GÜNTHER, H. 20 anos de pós-graduação: o que fazem nossos mestres e doutores? Uma visão geral. Ciência e Cultura, São Paulo, v. 38, n. 10, p. 1643-1662, 1986.

STRICKER, G. The doctoral dissertation in clinical psychology. Professional Psychology: Research and Practice, Arlington, v. 4, n. 1, p. 72-78, 1973.

VELHO, L. Conceitos de Pós-Graduação ou a que finalidade serve a Pós-Graduação nos Estados Unidos e na Europa. In: VELLOSO, J. (Org.). O ensino superior e o Mercosul. Rio de Janeiro: Garamond, p. 85-98, 1998.

VELLOSO, J. (Org.). A pós-graduação no Brasil: formação e trabalho de mestres e doutores no país. Brasílià: Fundação Coordenação de Aperfeiçoamento de Pessoal de Nível Superior, 2002.

WYATT, J. The lenghtening shadow of one man: the public intellectual and the founding of universities. Higher Education Review, v. 30, n. 2, p. 29-49, 1998.

\section{NOTA - Endereço dos autores}

Universidade Regional de Blumenau

Programa de Pós-Graduação em Ciências Contábeis

Rua Antônio da Veiga, 140 - Victor Konder

Blumenau - SC

89012-900

University of Illinois at Urbana-Champaign

College of Education

Department of Human Resource Education

353 Education Building

1310 South Sixth Street

Champaign - USA

IL 61820
Universidade de São Paulo

Faculdade de Economia, Administração e Contabilidade

Departamento de Contabilidade e Atuária

Av. Prof. Luciano Gualberto, 908, prédio 3 - Cidade Universitária

São Paulo - SP

05508-900 